Portland State University

PDXScholar

1971

\title{
Inter-bureau power relations; a sociological analysis of an ideal type organizational model
}

Gerald Wayne Potterf

Portland State University

Follow this and additional works at: https://pdxscholar.library.pdx.edu/open_access_etds

Part of the Organization Development Commons, Place and Environment Commons, and the Work, Economy and Organizations Commons

Let us know how access to this document benefits you.

\section{Recommended Citation}

Potterf, Gerald Wayne, "Inter-bureau power relations; a sociological analysis of an ideal type organizational model" (1971). Dissertations and Theses. Paper 1475.

https://doi.org/10.15760/etd.1474

This Thesis is brought to you for free and open access. It has been accepted for inclusion in Dissertations and Theses by an authorized administrator of PDXScholar. Please contact us if we can make this document more accessible: pdxscholar@pdx.edu. 


\section{AN ABSTRACT OF THE THESIS OF Gerald Wayne Potterf for the \\ Master of Arts in Sociology presented August 12, 1971.}

RAtle: Inter-Bureau Power Relations: A Sociological Analysis of an Ideal Type Organizational Mods:

APPROVED BY MEMBEKS OF LAE THESIS COMMITEE:

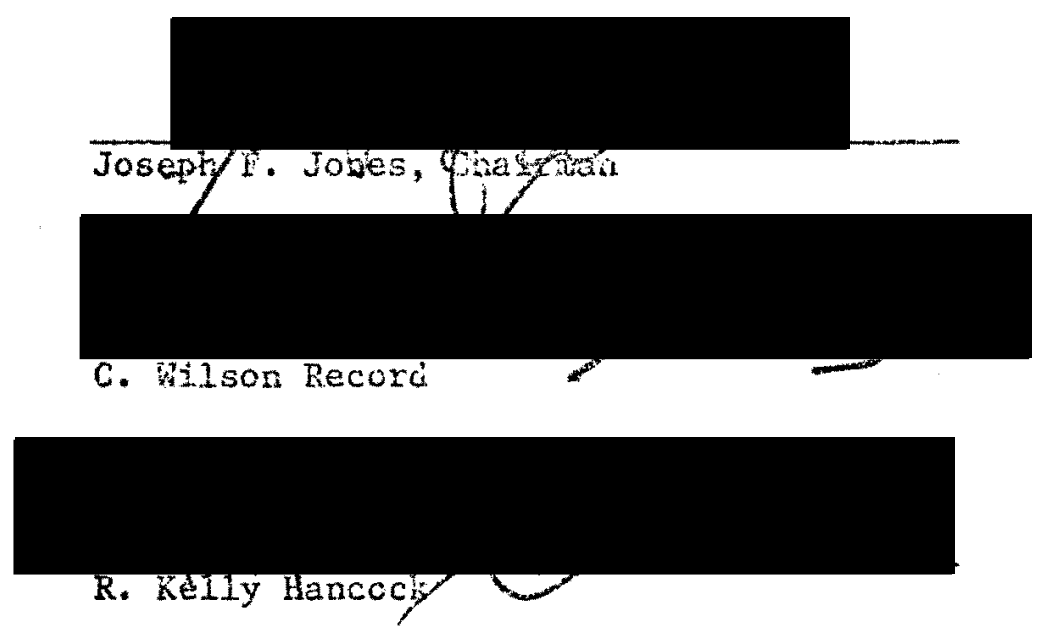

The research problem of this thesis is an examination of interbureau power relations. A modification of Max Weber's classical iakal type bureaucracy is the sonceptual model to which socioiogical analysis is made. An empirical examination of the variance between the conceptual mocel and data collected is the field is analyzed in order to Mustrate inter-bureau power reiztions. The analysis of the concentual. nodel is based upon three assations. They are: (1) inter-bureau power relations are based upon ccercior and not cooperation; (2) nornative standards that are estajolished by the acmintstrators of the bureaucracy are differcntially enforced; and (3) goais that are established 
by the administrators of the bureacracy are subject to distortion.

Participant-observation and casual interviewing techniques were the methods employed to collect data pertaining to the nature of interbureau power relations over a nine month period. The research problem lent itself to a qualitative approach in that the data were largely subjective and required recovding over a period of time. The data collected were primarily a revult of participant-observation conducted while an employee of the bureaucracy studied. Additional information was coliected and analyzed from documents related to the functioning of the bureaucracy. Permission was sought and received, from the bureaucracy and related organlzations studied, to use the data collected.

This study found that the Weberian styled conceptual model, representing the authority hierarchy of the bureaucracy studied, was theoretically based upon cooperation, rationality, logic and equalitarian principles. Maintaining the Weberian styled authority hierarchy had become ideology to the administrators of the bureaucracy. The existence and operation of this particular nierarchy was made a matter of public record, thus satisfying the political aspects of public accountability. However, it was found that there were other oiganizational hierarchies that the administrators of the bureaucracy utilized in performing the operational functions of the bureaucracy. For the purposes of this thesis the "ther" authority hierarchies were known as working models. The authority hierarchies of the working models seems to be operationaliy based upon the concepts of coercion, differential enforcement of normative standards, and distortion of administrators' 
8oals. A unique charecteristic of the working nodels vas that they were quasi-secret, and virtualiy no public records were kept of their existence of operation. 
TYTER-EUREAU DOWER RELATEONS: A SOCIOLOGICAL

ANAIYSIS OE AN IDEAT TYFE

ORGANIZATIONAL MODEL

by

GERALD WAYNE POTTERT

\footnotetext{
A thesis submitted in partial fulfillment of the requirements for the degree of

MASIER OF AKTS

in

SOCISICEY
}

Portland State University

1971 
TO THE OFFICE OF GRADUATE STUDIES:

The members of the Committee approve the thesis of Gerald Wayne Qotterf presented August 12, 1971.

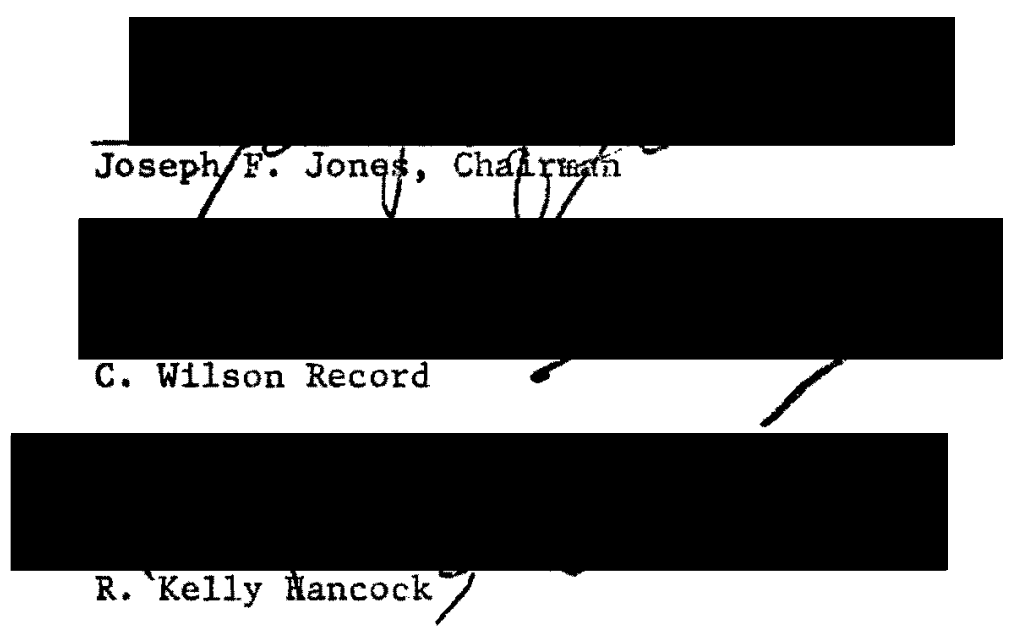

APPROVED:

Leonard D Cain, Acting Head, Department of Soclology

David T. Clark, Dean of Graduace Studies

August 12, 1971 
TABIE OF CONTENT'S

PAGE

LIST OF FIGURES . . . . . . . . . . . . . . . .

CHAPTER

I A THEORETICAL PERSPECTIVE . . . . . . . . . 1

Introduction ............... 1

Methodology ................ 1

The Problem............... . . 4

II REVIEW OF THE LITERATURE . . . . . . . . . 6

Weber's Ideal Type Model . . . . . . . 6

A Critical Analysis . . . . . . . . . . 11

The Role of Coercion in Inter-Bureau Power

Relations .................

Differential Enforcement of Rules and

Regulations .............. 16

Inter-Bureau Distortion of Goals . . . . . 20

Bureaucracy in Perspective . . . . . . . 23

III AN EHPIYICAL EXARPLE . . . . . . . . . . . 25

Introduction . . . . . . . . . . 25

Park Site Sclertion: An Empirical Example of

Real and Ideal Power Relations . . . . . .

The Neignbortood . . . . . . . . . . . 26

Background of the Park Site . . . . . . . 27

Fark sjta Salection............. 28 
PAGE

CHAPTER

IV FINDINGS: IDEAL TYPE AND WORKTNG MODELS . . . . . 36

A. Working Model: An Urban Renewal Agency . . . . 36

Organizational Structure of the Urban

Renewal Bureaucracy .............

Bureaucrats and Residents: The Real and Ideal

Nature of the kelationship . . . . . . . . .

The Role of the Community Association in

Relation to Achieving Bureaucratic Goals:

An Overview . . . . . . . . . . . . . . .

V

CONCLUSIONS ...................

What Has Been Discussed . . . . . . . . . .

Some Lessons Learned . . . . . . . . . 61

Thoughts for Future Study . . . . . . . . 63

REFERENCES . . . . . . . . . . . . . . . . . . 64 


\section{LIST OF FIGURES}

I Weber's Ideal Type Bureaucracy . . . . . . . . . 10

II A Working Mode1. . . . . . . . . . . . 18

III MDC Park Plan A . . . . . . . . . . . 32

IV MDC Park Plan B............... 33

V An Idea1 Mode1 . . . . . . . . . . . . 38

VI A Working Mode1 ............... 40

VII The Urban Renewal Bureaucracy: An Ideal Mode1 . . . . 43

VIII The Urban Renewal Bureaucracy: An Empirical

Example. . . . . . . . . . . . . . . . 44

IX HDCA Meetings . . . . . . . . . . . 53

X Proposed Timetable for Processing the Hayes District Urban Renewal Plan Supplement . . . . . . . . . 56 
CHAPTER I

\section{A THEORETICAL PERSPECTIVE}

\section{Introduction}

The purpose of this thesis is to critically examine inter-bureau power relations of a specific bureaucracy. ${ }^{1}$ (Inter-bureau power relations refers to the relationship maintained between bureaus ${ }^{1}$ that form a single bureaucracy on the basis of super and subordination). A refinement of Max Weber's classical presentation of the ideal. type is created in order to establish a conceptual frame of reference for this study. This frame of reference is designated the "Weberian Ideal type nodel" (see Faris, 1966:980 on the use of conceptual models in sociological analysis). This model provides the conceptual structure for analysis of organizational inter-bureau power relations. Initially, four assertions are discussed in a critical analysts of the modifled Weberian Ideal type model (a discussion of this model is contained in Chapter II). This discussion is followed by an empirical examination of an actual bureau in an attempt to illustrate the varlance between the Webertan model and the empirical example. The findings of this exanination are presented in a subsequent chapter.

\section{Methodology}

For the purposes of this study the term bureaucracy, or complex

1. Terms are defined below. 
organizaticn, zefers to an administrative structure composed of separate agencies or bureaus which are managed by sets of officials on a super and subordination basis. Within a bureaucracy the term bureau denotes a component agency that has a fixed position on a hierarchical scale that is managed by its own set of officials; a subdivision of a bureaucracy.

With the title of "Assistant Director for Citizen Participation"1 for the McCannville Development Commission $(M D C)^{1}$, I was afforded a "ring side seat" in the observation and participation of the exercise of formal and informal power in the citizen participation realm of urban renewal. As an employee of the MDC, my duties included the recelving and understanding of the formal public goals of the Comnission and the proposed formal method of achieving goals. I found that while formally claiming an organizationat structure that I have designated the Weberian ideal type model, the organizatiori was forced to informally modify its formal authorlty hierarchy to achieve its formal goals (Becker, 1970:14).

I found that the participant-observation and casual interviewing techniques have several drawbacks. Primarily, data were collected in a nonstandardized wey, thus waking statistical type treatment anc analysis of information very difficult (Doby, 1954). Consequently, I had to depend on a more impressionistic interpretation of some of the data in order to make generalizations, thus potentially allowing bias to change the impression of emerging data (Doby, 1959). In reference

\section{Fictitious name.}


to the participant-observation nethod, Eugene Webb, et al., (1966:113) in his, Unobtrusive Measures, suggested that, " . . no natter how well integrated an observer becomes we feel he is still an element of potential bias." Thus, Webb's position was that an "observer may selectively expose himself to cata, or selectively perceiva it. . ." As a researcher ut1lizing the participant-observer technique, I felt webb's point was well taken. The greatest area for bias in this study is what M. W. Riley (Faris, 1966:1001) referred to as "the limitation to a spectfic role." As the "Assistant Director for Citizen Participation" for the MDC I was confined to a specific role, and it was from that role that most of the data for this thesis were collected. In an attempt to "counter-act" bias, informants were used to supply additiona: information and to confirm previously held notions, thereby acting as a check on potential distortions (Dean, 1954). Informants were used throughout this study, via the casual interview technique. Also; documents, minutes of meetings, memorandums, letters, etc., were collected on the basls of their pertinence to the study. Thus, a check system was developed to curb the effects of blas in interpretation of data. The particlpant-observation portion of this study was conducted over a nine month period, February,1970, through September,1970.

The theoretical perspectives for the interpretation of the data were primarily a result of a library search. The books and periodicals listed in the selected bibliography were chosen because of their seeming pertinence to the problem.

Permission was sought and recelved from the bureaus and organizations involved in this study to use data collected from them. 
The Problem

The administrators of some formal organizations appear to have adopted a form of administrative hierarchy that can be conceptualized as a modification of Weber's ideal type bureaucracy. The formal organIzation of some of these bureaucracies seem to follow Weber's description of an authority hierarchy, based upon super and subordinate relationships. I assert that the reality of inter-bureau power relations is somewhat aifferent.

My first assertion is that coercion, not Weber's concept of cooperation, serves to integrate bureaucratic elements that form the functional processes of a bureaucracy (Etzlon1, 1961b). This is demonstrated by an authority hierarchy based upon super and subordinate relationships of one bureau (in a chain of bureaus or within a bureaucracy) to another. Eules, "files", laws and regulations, etc., are not established to insure efficiency of goal attainment per se, but are established as rigid boundaries and strong coercive measures to prevent the exercise of power and decision making at certain bureaucratic levels. Thus, rules, laws and regulations provide a sanctioning base for those individuals not performing to predetermined expectations. Further, employee ratings and recomendations for promotions are not in reality based upon job knowledge or particular skill, but based upon the employee's ability and willingness to "play-the-game," and as a method to coerce those not overtly "cooperating" to so do. The role of these mechanisms is not indicative of voluntary or cooperative integration of bureaucratic elements, but a denonstration of the expectation thac employees may not cooperate and thereby require rigid control.

My second assertion is that the normacive standards estabilshed 
by the adinistration of a burealicacy are differentialiy enforced within bureaus of a given bureaucracy. By way of 1llustration, the administration of bureau $D$ (the lowest level bureau in a four level bureaucracy) may be expected to periocm certain established duties regularly by the administration of bureau $A$ (the highest administrative bureau in the bureaucracy), while the directors of bureau A might require another of its subordinate bureaus to take only cursory notice of the same required duties. Thus, the existence of uniform normative standards throughout the bureaucracy allows bureau A, via arbitrary use of sanctioning power, to control its subordinate bureaus. The administrators of subordinate bureaus may violate certain standards with the knowledge of the director of bureau A, but the leaders of bureau A retain the optional ability to apply sanctions to their sutordinate bureaus for those violations. Thus, the directors of bureau A by arbitrary use of authority over their subordinate bureaus greatly disrupt the authority hierarchy of $A$ to $B$ to $C$ to $D$. This practice is continued on the bureau level as well by the supervisors of individual bureaus.

My third assertion is that goals establislied by the directors of bureau $A$ are subject to distortion and manipulation while being "passed down" through the various administrations of subordinate bureaus, while the communication relating to the achievement of the goals tends to support the original goals intent, as the report of accomplishment passes back up the chain of bureaus to the directors of bureat A. Thus the administrators of bureau A tend to believe that much of the origlnal goal has been achieved; the "boss gets what he wants to hear." 
REVIEW OF THE IITERATURE

hieber's Classic Bureaucratic Model

Weber's theoretical analysis of the ideal type bureaucratic structure has been criticızed by some contemporary sociologists (Vatrencorf, 1959; Thompson, 1961; Udy, 1959) for only examining 1ts formal characteristics and ignoring the modifications that occur in actual practice. My purpose here is not to add still more criticism of the Weberian bureaucratic model, but to 11 lustrate Weber's ideal model as it pertains to inter-bureaucratic power relations and specifically that part of the Weberian model which relates to the authority hierarchy. The relation* ship of Weber's ideal structure to actual working models will be discussed in the following sections of this paper.

Victor Thompson (1961:12) suggests that Weber equates the development of modern bureaucracy to the evolution of society; that is, modern organizations have evolved from earlier fcrms by incorporating advancing speclalization:

In an earlier period organizations could depend much more on the "line of command." The superior could tell others what to do because he could master the knowledge and techniques necessary to do so intelligently. As science and technology developed, the supervisor lost to experts the ability to command in one field after another, but retained the right as part of the role.

Technology, combined with the ever increasing complexity of administration, has greatly modified the supervisor's role. He has maintained 
his power and authority through his "office," but has been forced to rely on specialized staffs or experts for technical knowledge and problem solving strategy. (The term "office," in this case, may be defined as a designated position within a bureau or bureaucracy that is highly defined in terms of duties and responsibilities, and is located on a vertical scale of super and subordination.) Defined areas of authority are well marked in modern bureaucracies. dividing the right to make a decision from the ability to do so. Thus the authority hierarchy is maintained and relationships of super and subordination are perpetuated. Crucial to Weber's position is that authority, representing the right to issue orders and expect them to be obeyed, is inherent in the office (Peabody, 1964). The office, by 1ts strategic placement and designation within a bureau or bureaucracy, represents power and authority that is inherent in the structure of the organization, thus in Weberian terms, it is definable as formal, rational and impersonal.

Peter Blau (1955:226) offers a useful differentiation between power and authority:

The distinctive feature of authorfty is that normative constraints affect compliance with directives. The fact that a person compels others to do his bidding by employing coercion or sanctions or threats is prima racia evidence that he does not have authority over then in respect to the conduct he seeks to bring about.

Individuals occupy the office and consequently wield the power of that office. The amount of power and authority then is regulated by the position that the office occupies within the bureaucratic hierarchy. The officehoider is appointed by a superior within the organization to hold a specific office. This appointment is theoretically based upon tenure, ability anc aerit. Thus, qualicies of charisma and leadership 
tend to play a secondary role in the selection of a new officaholdar. Weber (1968:956) states that:

Although managerial ideology still strongly contalns the charismatic image, bureaucratic organizations seek to avold dependence upon individuals by reducing relevant informatinn to classes, and organizational activity to routines which are activated when the apprupriate class of information is percelved.

Consequently, with the advance of specialization a greater stress on departmentalization and routinjzation of work activity has been created. The structure of a bureaucracy is manifested as a departmentalization of offices within a hierarchy in which each office has a place in a table or organizarion, a vertical hierarchical position in which the office is subordinate to another office(s). This placement of individuals within offices of the formally categorized structure becomes what Weber (1968) calls "the principle of official jurisdictionai areas," which is generally ordered by rules, laws and administrative regulations. The bureau, within a bureaucracy, is highly departmentalized, with each individual occupying a specific designated position within a department or unit. For each position there are official duties assigned, designated authority lines, and methodical provision established for carrying out rules and regulations (Weber, 1968). The formallty of this system is manifested by a means of a more or less complicated social ritual which by its nature symbolizes and supports the "pecking order" of various offices (Etzioni, 1961:47).

Such formality, which is integrated with the distribution of authority within the system, serves to minimize friction by largely restricting (official) contact to modes which are previously defined by the rules of the organization.

Thus the Weberian principle of office hierarchy and the channelization of comulatcation within it, clearly establishes a system of 
super and subordination. The methodolngy of inter-bureau communication is a highly controlled and regularized phenomenon. With established rules, laws and regulations routinizing and categorizing communication the hierarchical structure is reinforced, as options and decisions of Individuals become sanctionable for noncompliance with established procedures. This sanctioning process is based in part upon written documents (the "Iiles") which are preserved in their original forn and provide a managerial base. Inese documents provide a $\overline{\text { Iocai }}$ point for the exercise of authority by supervisors within a bureau. That is, "the files" provide regularized guidelines for office procedure, and a nonpersonalized base for sanctioning deviancy from the established routines. A supervisor has the option of saying, "it's nothing personal, but you know the rules." The supervisor is only supporting the established system of laws and regulations and is somewhat protected by the formal appearance of objectivity in this decision making process, an appearance formulated by this "screening" function of bureaucratic rules (Gouldner, $1954: 163$ ).

Weber's ideal tureaucracy is elaborated in Figure I. The solid arrows represent lines of authority on a superordinate basis--while broken arrows represent the channels of communication.

Bureaucracy $X Y$ is represented by four separate bureaus in a relationship of super and subordination. That is, bureau $A$ is superordinate to bureaus $B, C$, and $D$; while $B$ is subordinate to $A$, it is superordinate to $\mathrm{C}$ and $\mathrm{D}$, and so on, leaving bureau $\mathrm{D}$ subordinate to a.11 and superordinate to none. Formal communication between the bureaus follows the authority bierarchy, thus performing both hierarchy reinforcing 
FIGURE I

WEBER'S IDEAL TYPE BUREAUCRACY

Bureaucracy $\mathrm{XY}$

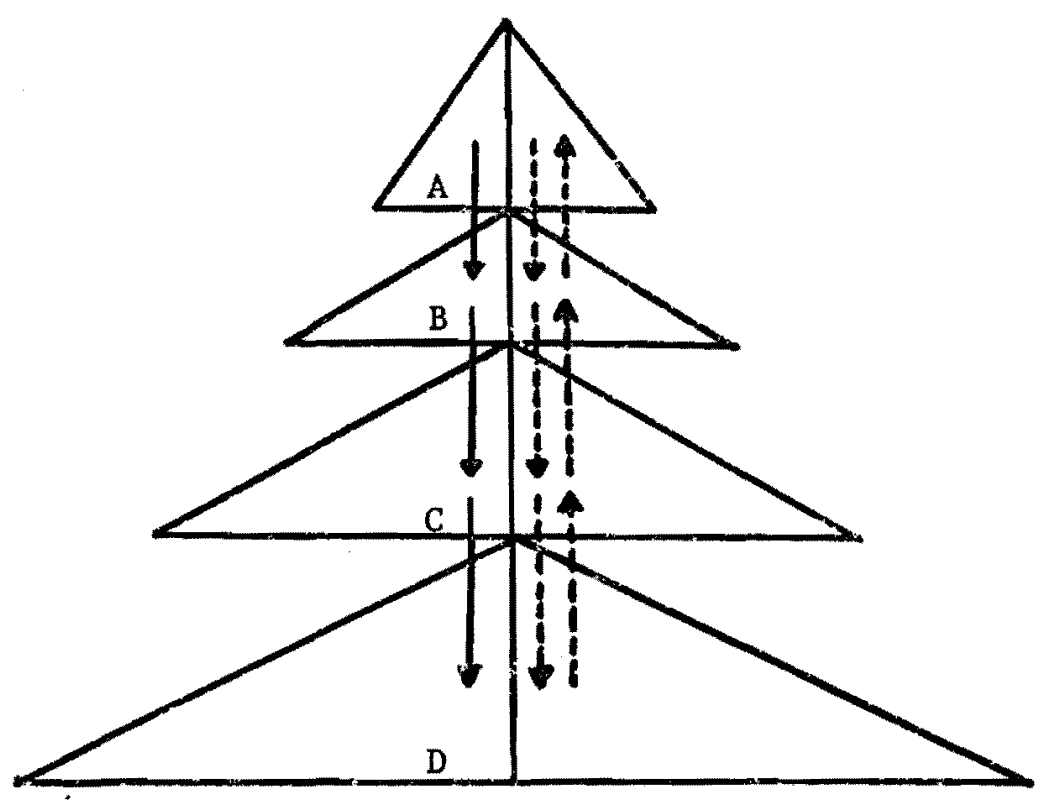


and boundary maintenance functions.

Maintenance of the hiexarchy is accomplished through the estabIishment of Iaws, rules and regulations. Bureau $A$, the head agency, maintains the superior position in the realm of inter-bureaucratic power relations in which it has overriding authority over subordinate bureaus. However, bureau $B$, while subordinate to A's dictums, also may require bureaus $C$ and $D$ to comply with its standards and rules, and $C$ likewise in relation to $D$. D remains subordinate to bureaus $A$, $B$ and $C$ and consequently is obliged to comply with their requirements. Thus, while subordinate bureaus may not disregard or veto regulations established by superordinate bureaus, they may add additional requirements or regulations for subordinate bureaus and expect compliance.

Once it is fully estab].ished, a bureaucracy is among the social institutions which are the hardest to change. Bureaucracy has developed as an effective instrument for institutionalizing power relationships. Consequently, a system of rationally organized reasons stands behind every act of a bureaucratic administration. The more the bureaucracy is "dehumanized" (or the more "rational"), the more it succeeds in eliminating from official business, love, hatred, and all purely personal, irrational, and emotional elements which escape calculation. In Weberian terms, this is the specific nature of bureaucracy, and its special virtue.

\section{A Critical Analysis}

The Role of Coarcion in Inter-gureau Power Relations. Crucial to the description of the Woberian authoritarian hierarchy is the assumption that comliance is based upon cultural vaives, societal norms, and associational roles (Uisbet, 1970). Therefore; the system of super and 
subordination is viewed as Legitinate in the minds of the organization's actors in light of the societai socialization process. Consequently, In theory, the actors within a bureaucracy spontaneously and willingly "obey those authoritles in which they can sense, however dimly, even subconsciously, the1r legitimacy" (Nisbit, 1970:140). Here the argument becomes somewhat circular in that authority is made legitimate "by the mores, by all the customs and folkways with which authority is commonly surrounded" (Nisbit, 1970:140). In short, Weber posits that bureaucratic systems are systems that assume cooperation and integration of their composite elements, rather then the coercion of them.

Upon examination of inter-bureau power relations, both theoretically and analytically, I found that the formal or public presentation of a bureaucracy generally followed the Weberian model. Organizational and manpower charts nominally supported the Weberian theory to near perfection, while designs of communication systems formally support and illustrate the super and subordinate channels of authority. Laws, rules, regulation and the "files" are additional written evidence of the applicability of the Weberian model.

My review of the mechanisms through which bureaucratic authority is exercised however; demonstrates an informal system of coercion and blatant authoritarianism that is far more influential in inter-bureaucratic power relationships than in Weber's formal model.

The nature of bureaucracy itself is based upon the concept not of cooperation, but of coercion, in that a hierarchy of authority is established in order to have maximum control over subordinates. Consequently, "bureaucratic authority is based not on devotion to the 
supervisor or respect for him as a person, but on an adaptation necessitated by his power (3lau, 1955:226)."

With these concepts in mind, one becomes aware of the conservative nature of bureaucracies. The authorjty hieraxchy is not necessarily designed to achieve zcals, Jut instead serves the function of punIsning those iscividuals failing to comply with established proceurures. Tnus, it would seem that bureaucracy is not generally designed for achievement or goal attainment, but for the prevention of failure of the bureaucratic system.

The advancement chance of officials and even their chances to keep their civil service jobs depend on the rating they periodically receive from their supervisor. Such an impersonal dependency creates anxieties and frustrations for most adults, and thus the need for adaptation (Blau, 1955:219).

Thus, what would overtly appear to be voluntary obedience to the supervisor, is in reality instigated through coercion (job security). The subordinates' concerm with his supervisor's opinion provides the supervisor with informal sanctions, since supervisory praise or blame becomes significant for every member of the group. Additionally, the supervisory practice of rewards and punishments for subordinates demonstrates that the supervisor does not expect unconditional obedience of his directives. A system of rewards and punishments within such a highly organized institution is clearly an example of the coercive nature of the supervisory aspect of bureaucracy, because one generally can only be "rewarded" for compliance with organizational directives established by the bureaucratic offictals. Reward is achieved through maximum compliance--while punishment tends to be IIiustrative of failure to comply with organizational directives.

A further illustration of the negative and coercive nature of 
bureaucracy was reported by Thowuson (1961:15):

Herarchical relations overemphasize the veto and underemphasize approval of innovation. Since there is no appeal from the supervisor's decision, a veto usually ends the matter. however, an approval will of ten go to the next higher level where it is again subject to veto.

The consequence of this particular authoritarian mentality is the suppression of innovation and deviancy and the promution of "status quoism."

The following iist of tactics avallable to supervisors as control devices is adapted from Downs $(1966: 144)$ :

1. The creation, development and implementation of rules and regulation. This has the ffect of reducing discretionary decision waking by subordinates.

2. "Development of distortion proof message codes for instruction." This reduces the subordinate option of saying, "I didn't understand what I was supposed to do."

3. "Vevelopment of objective measures of performance."

4. "Checking out proposed directives in advance with subordinates to insure that no extraordinary resistance will occur."

The first three of these measures are designed to reduce subordini. ates discretionary powers, hence instilling rigidity into the organization.

A further method of control is the requirement of keeping written reports of transactions and performances, which provide supervisors with a means of exerting control over their subordinates. These reports have three major purposes:

1. They inform high-level offlcials about what is happening In the loter levels of the bureaucracy.

2. The necessity of preparing periodic reports serves to remind each subordinate that he must meet certain standards of performance.

3. The fear of punishment for failure to meet those standards 
encourages him to carry out desired performances or at least report having done so (Downs, 1966:144).

The third point is perhaps the most critical one for the purposes of this paper-" the fear of punishment for fallure to meet those standards" is clearly indicative of the coercive nature of the bureaucratic kierarchy. The subordinate is not willingly complying to a supervisor's directive; he may be coerced into doing so by the threat of. sanctions. As Blau (1955) suggests, the ultimate source of burcaucratic authority is the official power of sanction, externally bestowed.

One of the most widespread and complex devices employed by a bureaucracy to control subordinate agencies is separate monitoring organizations.

The purpose of the external monituring service is to determine the extent to which compliance to established procedures is being maintained. Thus, the monitoring service is another mechanism for the maintenance of the status quo nature of the bureaucracy by the discovering and reporting areas of noncompliance, thereby providing still another basis for issuing sanctions.

Bureaucratic rules are particularly 1llustrative of the coercive nature of bureaucratic hierarchies. Rules comprise a functionai equivalent for direct, personally given orders. Like direct orders, rules specify the obligation of the rorker; hence, rules serve to narrow the subordinates area of discretion. Subordinate's have fewer options concerning what they may or may not do, and the area of "privilegs" is crowded out by the growing area of "obligation" (Gouldner, 1954:163). The public nature of rules enables deviancy to be detected by any supervisor, thus eniarging the informattonal chennels open to the heads of 
bureaus and in turn enabling them to keep thej.r own subordinates in Iine (Gouldner, 1954:163). Official sanctions ncrinally occur within the framework of these pre-eristing rules of the organtzation. Rules, ther. form both a potential sanctioning base for supervisors and also represent boundaries of obligatory behavior.

What has been discussed to this point is the reality of bureaucratic power relations. Of some sociological significance is the degree of divergence between the formal public presentation of the bureaucratic power structure compared to the informal or real nature of the organization. In the public presentation of its organizational structure, the bureaucracy appears to be rational, equalitarian, and just, with its authority hierarchy established as being both legitimate and humane. Efforts are instigated by "top-level" management to promote this image both internally and externally. Continual propagandizement of the Ideal model to the actors within the bureaucracy and to the society at large performs the function of making any deviancy from the Ideal model seem to be only a local or isolated problem, and therefore, not ubiquitous to the system itself. However, an examination of the mechanisms by wich a bureaucracy operates has revealed a rigidiy authoritarian and coercive structure. Its nature relies on power relations rather than cooperation for its functioning; consequently a bureaucracy is ortented towards "status quoism" rather than achievement and Innovation.


enforcement of rules and regulations will be discussed on both the interbureaucratic ari bureaveratic levels. 
Normative standards, as manifested through organizational rules and regulations, may receive differential enforcement between the bureaus of a single bureaucracy. That is, action agency $D$, at the bottom of the model (see Figure I, P. 13), might be expected to perform certain universaliy required duties by A, the "head" bureau, while A might require subordinate bureau $B$ only to take cursory notice. The exiscence of normative standards allows A to control, via sanctioning power, its subordinate bureaus. Bureaus B, C and D may violate certain standards with the knowledge of $A$, but A retains the optional ability to sanction its subordinate bureaus for those viclations (Blau, 1955). The result of this cverriding authority is a significant compromise of the ideal model. In that $A$ may sanction $B, C$, or $D$ without using designated channels of $A$ to $B$ to $C$ to $D$, likewise, $B$ may exercise the same option in regard to $C$ and $D$, as illustrated in Figure II.

Bureau B, represented by the black bar, may or may not maintain the same relationship to bureaus $C$ and $D$, depending upon the discretion of A.

Bureaus $C$ and $D$ in this model have the same informal and formal authority and communication channel because of their placement within the hierarchy.

The solid bar and arrows on the left of the figure represent the actual or informal authority and communication channels that bureau $A$ has the option to exercise in an attempt to assure interbureaucratic compliance with normative standards. This model illustrates a violation of its counter-part, the ideal model, in that the powers of subordinate bureaus are usurped by bureau $A$ by by-passing them in an attempt to deal direct!y with all ievels of the bureaucracy. 
FIGURE II.

A WORKING MODEI.

Bureaucracy $X Y$

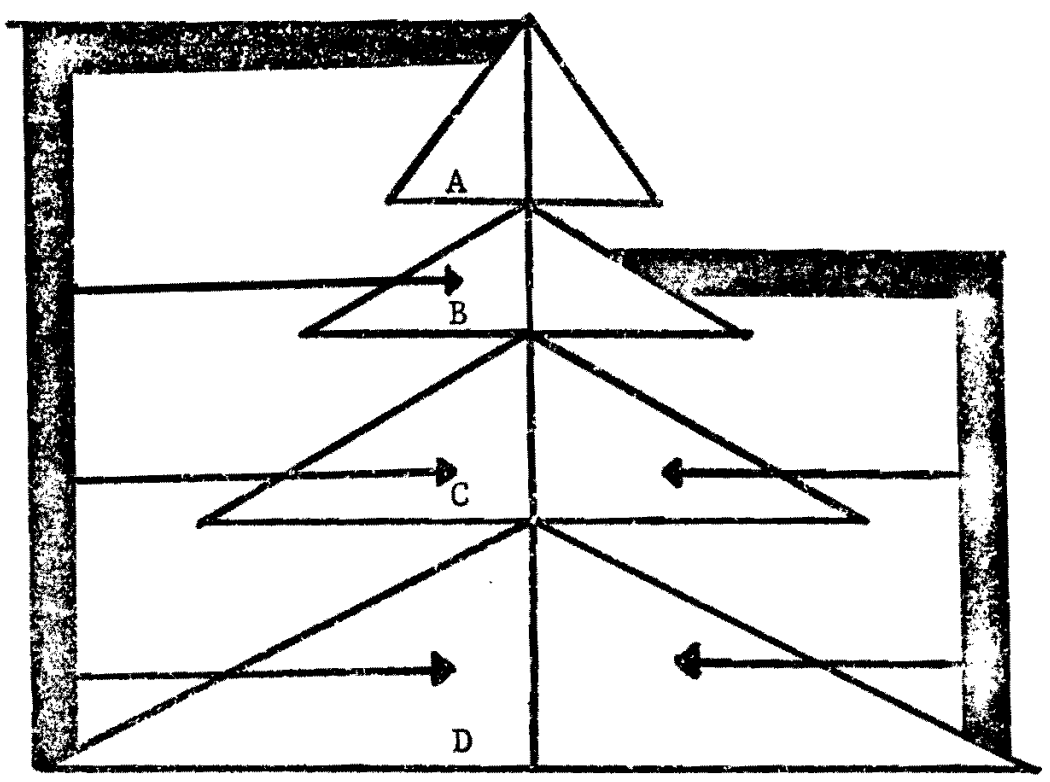


It should be noted that this is an example of how one working model may operate within Bureaucracy $X Y$, and is not meant to be the exclustve working model of the bureaucracy. As circumstances and events evolve within the bureaucracy, the working model also tends to adjust to the changing situations.

Differential enforcement of rormative standards (rules and regulations) is perhaps mosi obvious within a single bureau because the supervisor is responsible for all operations within his department and is consequently reliant to some degree on the ccoperation of his subordinates. The fact that he may occasionally yield to some of their collectIve demands indicates that the group can exert some Influence over his decisions. These concessions however, tend to furnish him with discretionary sanctions and create social obligations which extend his power and establish his authority over every individual subordinate. As a result, his authority is validated through social interaction which enables him to control his subordinates much more effectively than they control him (Blau, 1955).

According to Blau (1955:214), when a new supervisor takes over a department there is an initial period of leniency which allows the supervisor to:

1. Use suborainates' first names in order to foster cordial relations.

2. Never issue commands.

3. Always make polite requests.

4. Explain reasons for directions.

5. Show wlilingness to rescind directives if subordinates desire it.

6. Demonstrate willingness to help suboralnates "get ahead." 
7. Peruit suborainates to break minor rules.

The rationale of the abcve techniques is to create social obligations of subordinates to the supervisor. Thus, toleration and lenfency towari exceptional or even illicit practices vill actually enhance the power of a supervisor, i.e. a rule that is regulariy broken extends the discretionary power of the supervisor, because it furnishes him with a base through which he can issue legitimate sanctions when he sees fit.

By voluntarily relinquishing some of his prerogatives, the supervisor created social obligations. His requests for cooperation when he could issue orders, his promises for future help, his toleration of prohibited practices and sperial favors for agents, his references to his identification with them and his considerate manner-all these serve to obligate his subordinates to him (B1au, 1955:21.5).

Ideally then, the supervisors appear to be somewhat altruistic in their approaches to management, supporting their subordinates whenever possible, but in reality this support is manifested in the control the supervisor gains over his subordinates by creating social and personal obligations to himself.

Inter-Bureaucratic Distortion of Coals. The formal public function of all the activities within a bureaucratic hierarchy is the achievement of goals. Ideally, the crganization is structured for the "effective" accomplishment of the purpose. Simply speaking, bureau A is primarily interested in controliing the bureaucracy in order to achieve its goals to the greatest possible extent.

The head of bureau A (theoretically the most powerful individual in the bureaucracy) oversees many policies; consequently he must formulate each one in broad general terins, and does not have time to work out the details. The detalls, then are left to subordinates to 
be worked out. Therefore, the orders of top-level management are almost always general in nature (Downs, 1966).

Top-level officials cannot review everything done by subordinates in response to their orders. It might seem, therefore, that they might review the most important responses, or those likely to be executed badly. However, if their selection for review can be easily forecast, subordinates will have great discretion regarding those orders that will not be reviewed. This will drasticaily reduce official control over the organization (Tullock, 1965:186).

The meaning of the last passage is significant in that it suggests the need to use coerclve methods in order to gain compliance from subordinates who would not otherwise comply with the orders given them. The Weberian model posits that bureaucratic activity is both rational and predictable because the source of authority is located in the office as opposed to being located within the individuals who occupy the office (Peabody, 1964). This approach tends to ignore the motivations and attitudes of the human beings working within the organization. Anthony Downs $(1966: 135)$ in his work, Inside Bureaucracy, states that:

There are very few orders so precise and unequivocal that they cannot be distorted by a factor of $10 \%$; consequenty, $B$ 's orders to his C level subordinates embody only $90 \%$ of what A originally desired. C level will aistort because its goals w1ll be different, if only slightly, from $A^{\prime} s$ and $B^{\prime} s$. If sinflar distortion occurs by the time $A^{\prime} s$ orders get to $D$ level they will contain only $53 \%$ of A's original goals.

Downs terms this process "authority leakage" and suggests that it is a common phenomenon when orders are passed down through levels of a hierarchy, and that this leakage tends to become cumulative when many levels are involved. What, in reality happens, then, is that administrators of bureau $B$ believe that a slight distortion of the order can help him personally, or he may consciously or subconsciously distort 
orfers so that his bureau will be best benefited. Thls concept vould loglcaliy apply to bureaus $C$ and $D$ as weil. A bureaucracy must contend with not the smooth functioning of the 1deal model, but the varying personalities, abilitles, attitudes, memorles, images of goals, etc.: of the individuals who occupy offlces within the structure. The following is an adaptation of a mechanism Downs labels the "basic control cycle."

1. An official 1ssues a set of orders.

2. He allows his subordinates time to put each order into effect.

3. He selects certain orders to evaluate his subordinates performances.

4. He seeks to discover what has actually been done at lower levels as a result of the orders.

5. He compares the effects of his orders with his original intentions.

6. Evaluates results of the order and selects appropriate action.

7. If he elects to issue further orders as a result of his evaluation, the cycle starts again (Downs, 1966:144).

If the hierarchy functioned as the public formal model suggested, actual control of the activities of the bureaucracy would be in the hands of the top-level management. However, those officials must always delegate some of their power to subordinates; hence the "rub," and the need for anti-distortion devices to obtain compliance. Individuals within the organizational structure are subject to the attributes and failings of humans, and consequently require monitoring, direction, coaching and must be generally coerced into the proper performance. Weber suggests that organizations, as problem solving mechanisms, 
defend upon factoriag of the general goal into subgoals and these subgoals inco sub-subgoals and so on, until concrete routines are reached (Thompson, 1961). These subgoals are allccated to the organizational units or departments and become their goals. This pattern is indicative of the "order giving" process. That is, in passing orders downward, subordinate bureaus must translate commands received into more specific and expanded form. As we have previously discussed, this 1deal bureaucratic function does not take into account the human element and as a consequence a system of formal and informal sanctions and rewards has been created to account for and motivate the human actors.

Bureaucracy in Perspective. Bureaucrats, though publicly and formally defending and supporting the Weberian model, have had to compensate for that model's inability to cope with daily operational functions by creating an informal "working" model. This informal model may vary from organization to organization, but one may say, with sone assurance, that it inevitably exists.

of considerable importance is the latter model, in that it enforces conformity, and threatens innovation at lower levels as deviancy, thereby assuring a spirit of benign "status quoism." As Downs (1966:50) posited:

While the tendency of administration may appear to be benign and peaceful, as opposed to turbulence of conflict, it is actually violent. It demands compliance; nothing less than compliance will do; and it must obtain compliance, by persuasion or management if possible, by repression if necessary.

In essence, the nature of the mechanisms of the actual operation of a bureaucracy are strongly coerclve in demanding compliance to established procedures, and in Downs' terms this "imposed order [comp.liance] is violent."

This concept is further amplifted when one considers that the 
administration of 2 bureaucracy rejects the concept of conflict as a desirabie element of soclety. The administration wants extremes adJusted; it wants differences settled; and prinarily, it wants to find a set of procedures that it can use exclusively within the organization. Whatever or whoever refuses to be adjusted is considered by supervisors as a deviant, a departure from the norm that must be treated and cured. Consequently:

biscipline and control may inhibit initlative and creativity. on the part of subordinates. They may hesitate to assume or go out of their way to avoid responsibility. A worker may tell his boss what he thinks his boss wants to hear. Despite these potential inhibiting and disruptive consequences, authority remains an inevitable aspect of complex organizations (Peabody, 1964:10).

In sum, the system that is largely responsible for the administration of this country is treating procedure and knowiedge as absolute, and establishing mechanisms of control and operation to insure accpetance by the actors within the organization. With the advent and rapid adoption of technology and technological change in our society, it would seem more appropriate to view knowledge and procedure as relative, as opposed to absolute. 
CHE.PTER III

AN EMPIRICAL EXAMPLE

\section{Introduction}

The intent of Chapter III is to preseat a description of an event in the urban ronewal process on the action agency levei. The event, the selection of a park site, is treated in terms of "what" happened in this section; while the analysis of the selection process will be discussed in Chapter IV. Chapter III, then, illustrates an empirical example of inter-bureau power relations as they are manifested in the urban renewal process on the bureau level. The relationship to the Weberian model in a technical sense will be discussed in the subsequent chapter.

\section{Park Site Selection: An Empirical Example}

The McCannville Development Commission (MDC) will be the bureau discussed, and the selection of a park site in the Hayes District will be the empirical example through which the above concepts will be examined.

The selection of the park site in the Hayes District was chosen for analysis because: (1) it affords an empirical example of the concepts of citizen participation; (2) it provides a link between interbureau and bureau relations; and (3) it further illustrates the working and ideal type bureaucratic models. (The term working model refers to an emplrical administrative structure composed of separate bureaus, or 
departments vithin bureaus, that may or may not conform to the estabiished organizational structure.)

According to Department of housing and Urban Development (HUD) regulations, the residents of the Hayes District would, through their conmuntty association, assist the MDC in the planning, selection and execution of a park site in their neighborhood. But the extent of citizen Involvement in the actual selection of a park site was the enäorsement of a Comnission developed and sponsored plan. This is in essence the thrust of this chapter.

The Nelghborhood

A broad view of the District which is the context for park site selection can be briefly sketched as follows.

During the study, the Hayes District was primarily a residential community covering about 360 acres in the city's Northeastern section. of the 1,500 homes in the District, $95 \%$ were single family houses. Although no detailed survey had been made as to the physical conditions of the houses in the District, a "conservative" estimate would have been about $30 \%$ in substandard conditions, half of which could be called dilapidated.

There were about 35 businesses in the District, whose clientele were primarily drawn from outside the district. The few businesses that serve mostly the Hayes District were, to a large extent, in substandard buildings with no off-street parking.

Comunity facilities serving the District were: one public elementary school, three churches and an old fire house converted into a youth center. Thera were no parks in the District itself. 
There are approximately $1 \% 1 / 2$ miles of streets in the District; about 1/2 were either unpaved or in substandard condition with only a narrow paved strip down the middle of the right-of-way.

Of the residents, approximately $35 \%$ were black, $55 \%$ were 65 years or older, and $75 \%$ wade $\$ 5,000$ a year or less. ${ }^{1}$

In relation to the whole Northeastern section of the city the Hayes District represencs a fair approximation of the average neighborhood, it is not the most bilighted area, nor is it the nost prosperous. When compared to overall McCannville residential standards, it was easily a substandard neighborhood.

Background of the Park Site

The initial idea of a park for the Hayes District was develoyed by the Mcannville City Planning Comissicn, ${ }^{2}$ the city agency responstble for long range comprehensive cfty planning. The MDC was advised of this plan, and agreed to incorporate the proposed park site in its application to HUD for Neighborhocd Developrent funds. 3 then the program was approved by HUD, and the funds allocated, the Commission was committed to developing a park in the Hayes District. As far as the park was concerned, the Commission's goel became the coordination of the Hayes District Community Association (HDCA) with the various city agencies

1. Taken from a document about the "Hayes District" written by the author while an employee of the Commission.

2. Commission docurent concerning citizen participation in the "Hayes District," September 11, 1970, p. 4.

3. The Neighborhood Deveiopment Program is a federally funded urban renewal prograsn to which the Commission applied and received funds for the administration of , 
for the approval and execution of the park site portion of the Neighborhood Development Program (NDF) plan. The citizen participation staff of the MDC received the assignment of gaining citizen approval for the Commission's planned park. Since the park was included in the first year's program, HUD required that it be $80 \%$ completed by the end of the "action" year. (The action year was from July 1, 1970 to June 30, 1971.) Thus, early resident approval of the park site was imperative.

\section{Park Site Selection}

The MDC set the HDCA approval date for the park site as the 15th of April, 1970. In February, the director of citizen participation for the MDC informally brought the park site topic to the attention of the chairman of the HDCA. After several informal discussions, the cha1rman agreed to support a Commission planned park for the neighborhood. With the support of the chairman, the director of citizen participation next secured the support of the executive board of the HDCA. This was accomplished over a period of approximately two weeks.

The first official public mention of a park for the Hayes District was in a general membership meeting. Ger:eral membership meetings of the HDCA were open to all residents of the District. The meeting of the HDCA was held on March 10, 1970. The director of citizen particlpation for the Commission "requested that the executive board meet with the Park Bureau and other appropriate agencies in order to determine the location of the park." (HDCA General Membership Meeting, March 10, 1970).

There was no action taken on this request at this meeting; however, 
the supposition that there would be a park in the District had been introduced, made formal record of, and recelved no opposition. On the 24th of March, the executive board of the HDCA had a regular meeting. At this session, the director of citjzen participation "asked" that a special subcomittee of the HDCA be formed to "consider the location of a park site and work with the Park Dureau, City Planing Comension, MDC and other appropriate agencies in developing the park." (HDCA Executive Board Minutes, March 24, 1970). A subcomittee was fornad called the Physical Planning Comittee, wade up of executive board members of the HDCA.

It is limportant to note that a tentative park site location had been developed by the City Planning Comission in conjunction with the MDC and other "appropriate agencies," prior to any actual resident Involvement in the actual plenning.

At this meeting, a Mr. Thomas ${ }^{1}$ was elected by the executive board to be the HDCA's planning consultant. Mr. Thomas was a resident of the District and had been an active member of the HDCA since Its inception. Mr. Thomas was also a registered architect. (Several days after his election to his new post, Mr. Thomas was placed on the MDC payroll as the planning consultant to the Hayes District.) When asked by the chairman of the HDCA to act as the consultant to the Physical Planning Committee, he accepted.

On March 31, the Physical Planning Committee held its first meeting. Attending this meeting were the seven executive board members

\section{Fictitious nane.}


appointed to the conmittee and nine MDC members. After an election of officers for the committee, Mr. Thoras introduced the proposed park site. The nine MDC stafi were there to primariiy answer questions about the park site design and location. There was no opposition to the proposed plan. Mr. Thomas "reported that with this map (map refers to a map of the Hayes District) and the budget information, he would be able to work out a recommendation to the committee as to the park for the next meeting." (HDCA Physical Planning Comnittee, March 31, 1970).

On April 6, the Physical Planning Committee approvad the park site. This meeting was attended by five committee members and eight MDC staff, including the executive director of the Commission. The vote to accept the plan was unanimous.

Only one plan was presented to the comittee, and only their approval of it was sought. There was virtually no eftizen input in the design of the plan, nor was it sought, or asked for by the Commission. April 14 was the date set for the general membership meeting of the HDCA in which formal, public accpetance of the park site was to be attained. Since the chairman, the exacutive board and the Physical Planning Committee of the Association were already committed to supporting the plan, the Commission was relatively confident of its approval by the general membership.

Mr. Thomas introduced the proposed park site to over 100 residents attending the meeting (a record attendance for an HDCA meeting), by stating that the boundaries of the park had been selected by the members of the Physical Planning Committee (Physical Planning Comittee, March 31,1970 ) of the HDCA. After his presentation of the site to the residents, the MDC staff attending che neeting were available to answer residents' 
questions.

The unexpected happened; smaj.l groups of the residents began to strongly oppose the plan. It had become obvious to them that they were not being asked to particlpate in planning or dectsion making, but to approve an already existing plan. The issue became either accepting the plan, or not having a fark in the neighborhood. This put tremendous pressure on the chairman and the executive board, not to mention the IDC staff present. The leadcrship of HDCA and the technical "expertise" of the staff had been seriously challenged. The struggle between the residents and the leadership of the HDCA and the $M D C$ staff continued for well over an hour. A staff member (an engineer) suggested that an alternative plan be drawn up and presented at another meeting, thereby offering the residents a choice. As this became a motion and was being voted on, the chairman of the Physical Planning Comittee moved that the plan presented be tentatively approved. (This motion was made at the personal and private request of the director of citizen participation for the MDC.) Both motions were passed by majority vote of the membership. The next meeting of the HDCA genera? membership was set for April 20.

During the six days that ensued between the first and second meetings, the original plan was designated by the Commission as Plan A, (Figure III), while the alternate plan was to be known as Plan B, (Figure IV). Plan $\mathrm{B}$ was of rather interesting design in that it was cut in halt by one of the neighborhood's largest arterial thoroughfares, which meant: (1) that the park would be a potential trap for children playing on the fringes of the park near the road; or (2) that the road 


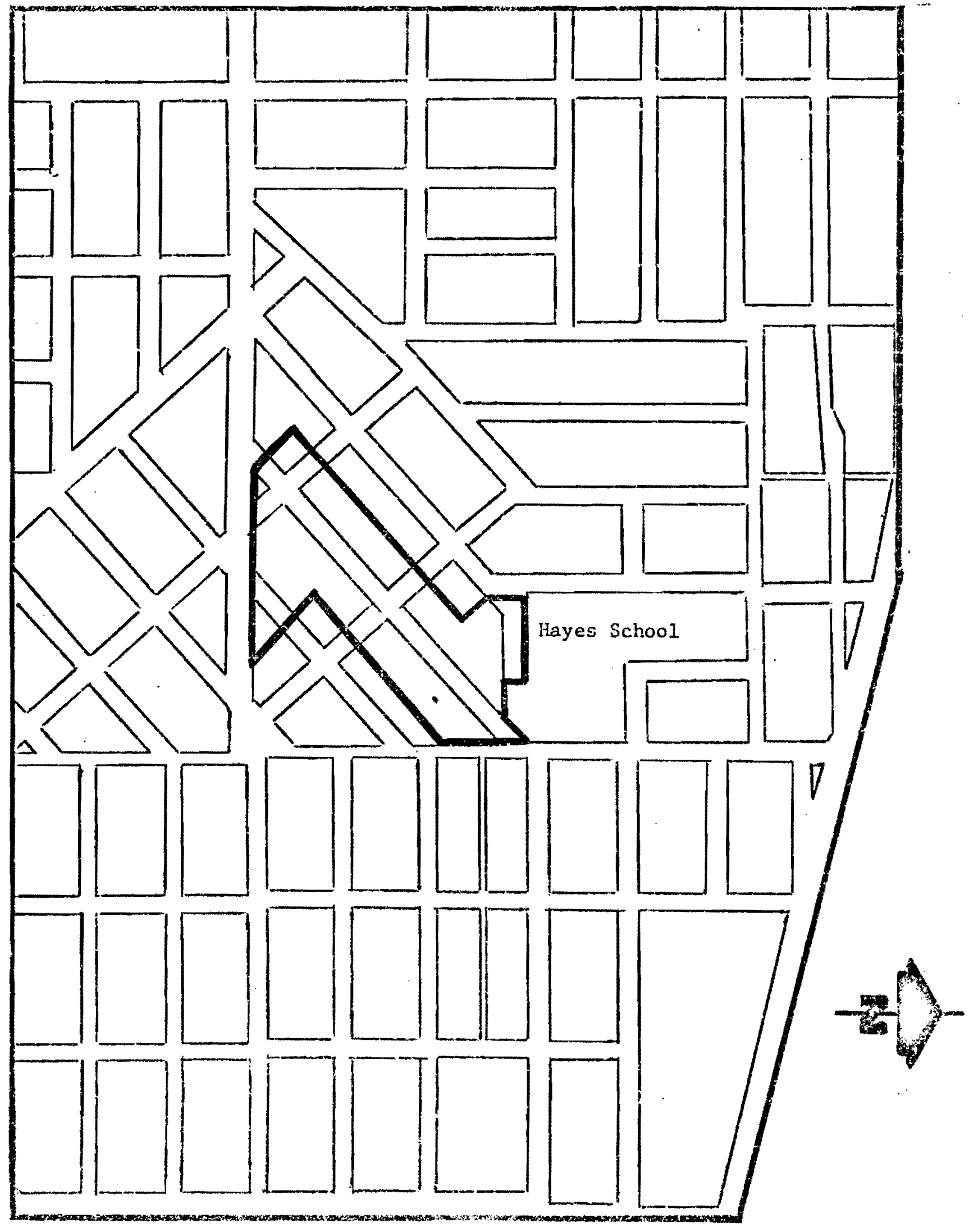


MDC Park Plan 3

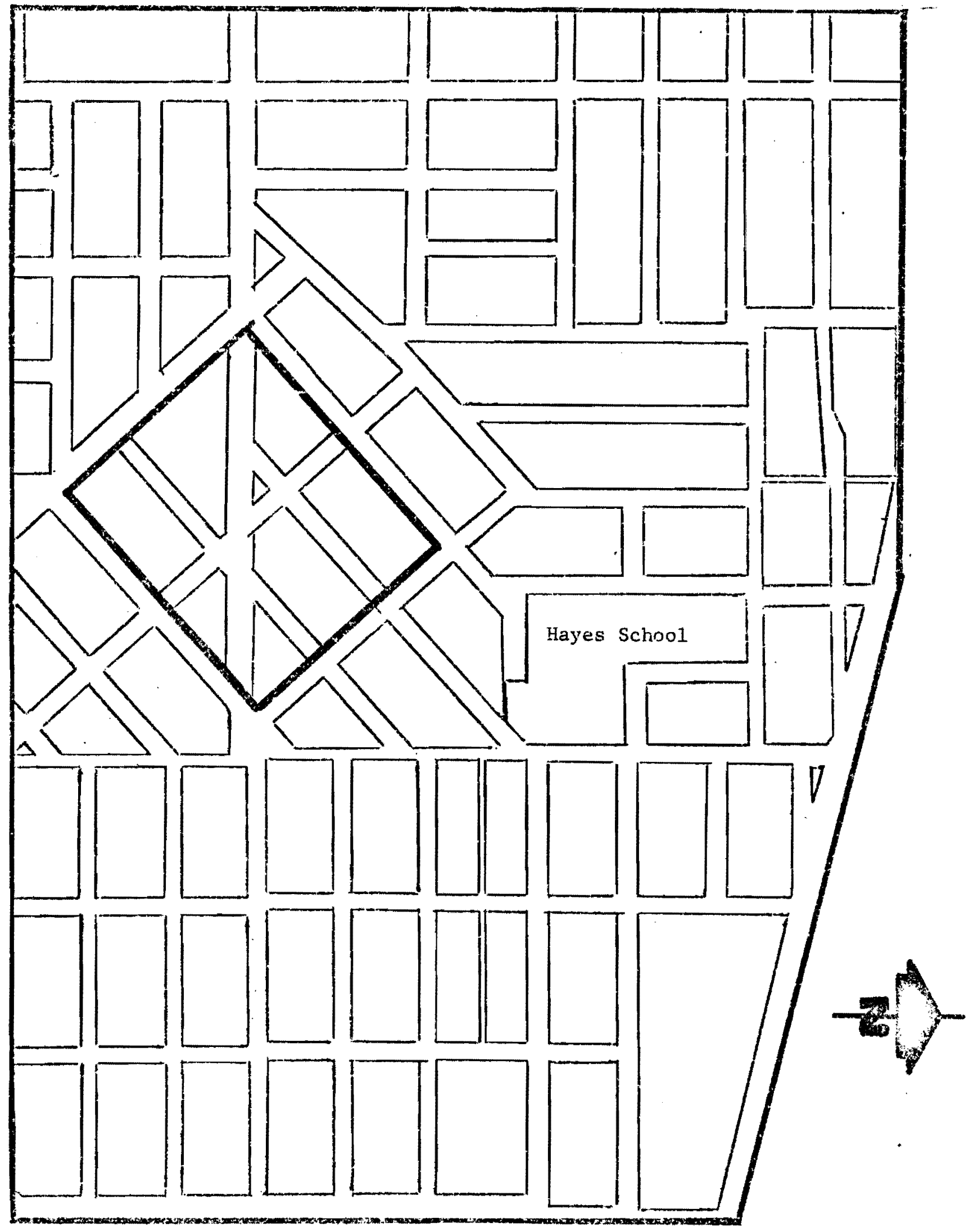


Itself would be closed, thereby civerting the thru traffic inco the residential streets around the park. The Ccmission decided it would be best to close the street.

Prior to the April 20 meeting of the HDCA, the citizen participation staff was able to reaffirm the sipport of the chairman, the executive board, and the Physical Planning Committee.

At the April 20 general membership meeting, Nir. Thomas presented both Plan $A$ and Plan $B$ to the residents. But now the issue had become whether to choose Plan A or Plan B, and not whether or not to have a park in the District. The residents, with very little staff assistance, decided that Plan A was superior to Plan B, and passed it by a majority vote.

In sum, the MDC was able, through the use of what I have identified as a working model, to achieve its goal, the selection and approval of a park site by the residents of the Hayes District, thus satisfying the requirement for citizen participation in the plannirg and development of community projects. In attaining resident approval for the park, the Commssion used both implicit and explicit coercion; it largely distorted the goal of citizen participation as outlined by HUD, and it differentially enforced not only HUD regulations but its own regulations as well. An informal working model of citizen participation was deve1oped in order to facilitate greater passage of the park site by the residents. The director of citizen participation, with the aid of an assistant, the author, successfuliy and informally contacted and received the support of the chairman of the HDCA, the Executive Board, and the Physical Planning Comnittee, prior to any formal meeting of the HACA or any of its subcomittees. The informal model continued in 
operation until final passage of the site by the general membership of the HDCA. Thus, in the selection of a park site in the Hayes District, both real and ideal models of citizen participation were illustraced as well as the concepts of coercion, distortion of goals and the difierential enforcement of rules and regulations. 


\section{CHAPTER IV}

\section{FINDINGS: IDEAL AND WORKING MODELS}

\section{A Working Model: An Urban Renewal Agency}

In the selection of a working model to illustrate the theoretical concepts of this paper, an urban rerewal burealicracy was shosen, the reasons for this choice were: (1) the nature of a federal non-profit organization seemed amenable to this kind of study; (2) the public "accountability" (public accountability is that aspect of control, both overt and covert, that a society maintains over instituticrs accountable to it to furnish explanations for its activities) of a federal bureaucracy; and (3) the autho:'s nine month participantobservation experience within an agency of the bureaucracy.

With these points in mind, we will initially examine the action agency itself, before presenting an overview of the whole bureaucratic system. I have chosen to call this action agency the McCannville Development Commission (MDC), as opposed to using its real name, for my purposes here are academic. That is, the primary interest of this study is the examination of some of the operational functions of $a$ complex organization, and is not intended to be material for an expose. Likewise, the city that supports the Commission will be known as McCannville. This city is located on the West coast and has a population of a half million, of which 50,000 are minority group members (nonwhites, primarily blacks). 
The McCannville Development Comaission is responsible for all urban renewal activities in the city; however, due largely to the availability of federal funds for urban renewal in black districts, many of the Commission efforts are fosused in the black inhabited Northeastern section of the city, (a topic to be dealt with in subsequent pages). The Commission was established by MaCanzville voters through a city charter amendment in 1958, and charged with the following:

. . . the Department of Development and Civic Prcmeticn. It is responsible for McCannville's urban renewal programs and assists in the promotion of commercial and industrial development. One of the Commission!smajor objectives has been to blend citizen participation with the roles of local, state and federal agencies in the planning and developient of its projects. (Taken from the actual Urban Renewal Commission's definition of its role in the community, pubiished in mimeograph form.)

Simply then, the MDC is responsible to the C1ty Council of McCannville for the city's urban renewal, with $a$ pledged emphasis on citizens' participation. To carry out this goal, the Commission was organized with a single chairman at 1 ts head, four commissioners and an executive director with a staff of approximately sixty to administer its various programs. The formal organization and power structure are illustrated in Figure V. It closely follows the Weberian 1deal model, in that it is headed by a chairman who wields ultimate power and authority, supported by four commissioners subordinate to him, but superordinate to the administrative staff: an executive director subordinate to the chairman and the commissioners, but superordinate to his staff, etc. LInes of formal communication generally follow the vertical lines of authority, 1.e. the submission of monthly activities reports inftiated in a fleld office will follow the vertical channels of authority as 1llustrated in Figure V. It is important to note that most formal activities (those of 
FIGURE V

THE IDEAL MODEL

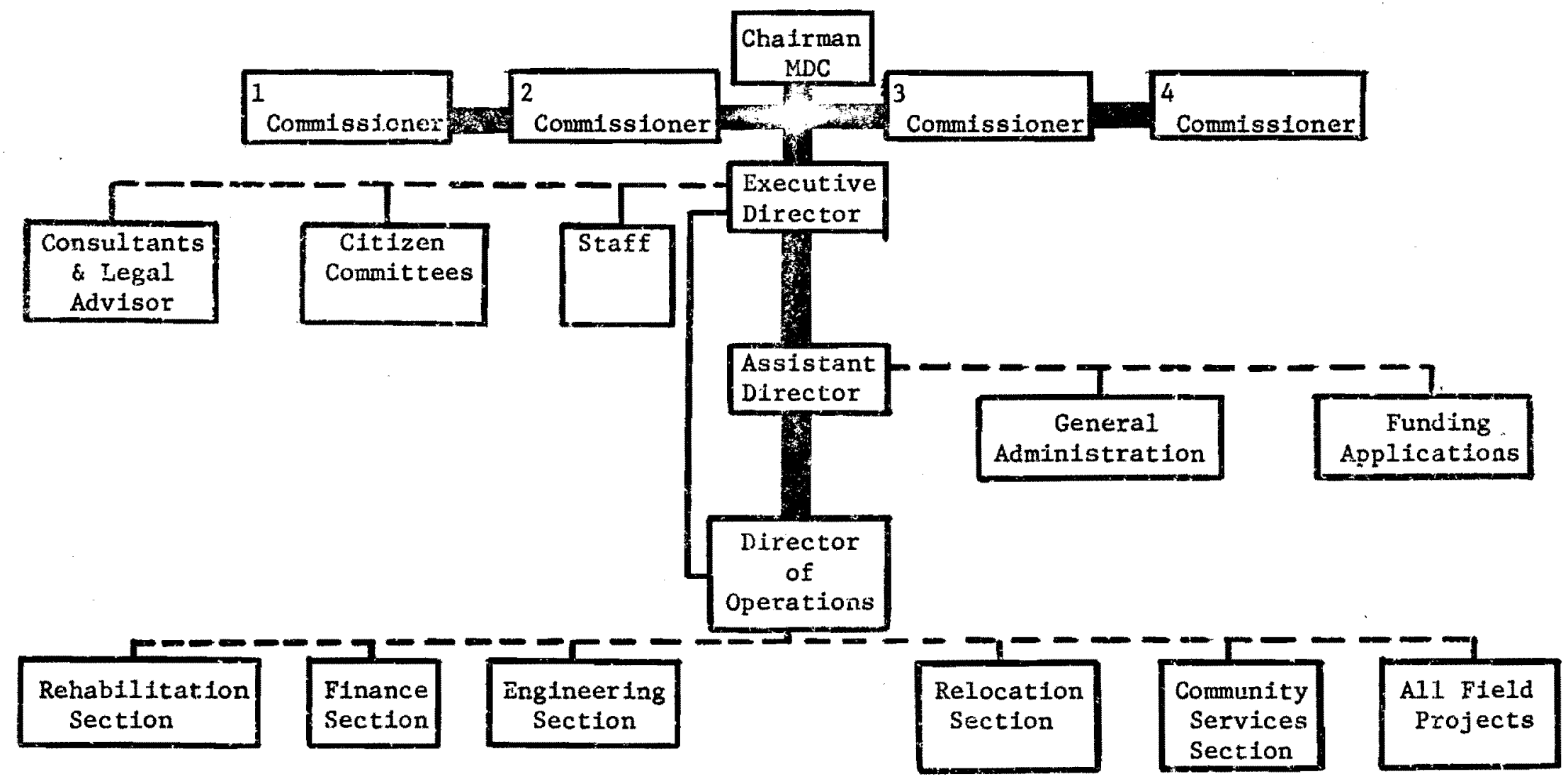

1. The black line represents the formal "chain of command" and communtcation channels with the brcken line 1llustrating supporting stafis.

2. The Director of Operations is subordinate to the Assistant Director in the command chain, but under the Executive Director on operations under his control. 
of a routine nature), gencrally follow the putlic ideal model. When an activity or decision does not require a policy type decision, the public model is followed. The reason for the presentation of the Weberfan like 1deal model, to the public and the staff itself, appears to be the legal requirement of public accountability of the Comnission. The nature of urban renewal activities in a comminity and the expenditure of federal funds place the Comission under the scrutiny of monitoring agencies of all kinds, the mass medta, groups and cluts of every description, as well as private cltizens. Therefore, whenever possible, the Commission presents 1tself as the ideal model bureau that is run by rational, logical design, with an expert technical staff, maximum citizen input, and an equalitarian chain of command. Figure $V$ then represents the formal public organization of the Commission's hierarchical structure.

Figure VI illustrates the actual working model when other than routine matters are at issue, 1.e. policy making, press releases (other than routine), hiring and firing of staff, special problems, etc. While activities carried out under the formal model are carefully documented and "filed" as a matter of public record, meetings of the working model tend to be Informal and unrecorded, thus the working model exists in quasi-secret form. This modification of the ideal model is necessitated by: (1) a need to by-pass channels when a time element is Involved; (2) the ineptitude of certain staff members in critical positions; (3) the generally clumsy nature of the ideal model; and (4) the unique position and personal capabilities of the five members of the working model to actually run the Comntsion somewhat competently. 
FIGURE VI

THE WORKING MODEL

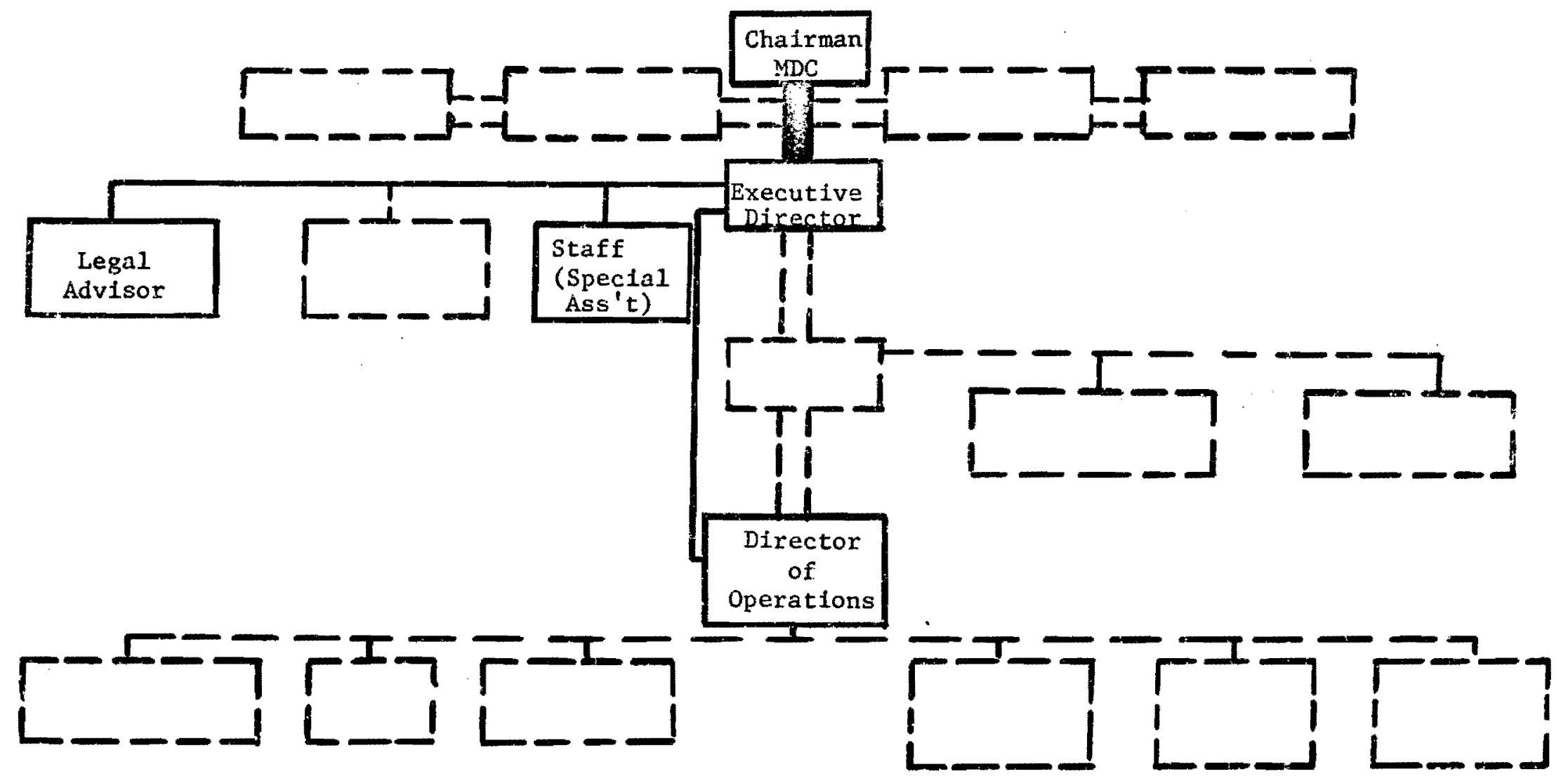

The connecting black line represents the actual "working" hierarchy of those who actually make deuisions within the Commission. 
The point is that the Comission maintains two hierarchies. The first is a formal public presentation of the agency wich is similar to the Neberian model of a rational monolith, with relationships of super and subordination, supported by expert technical staffs. The reason for this phenomenon is largely dus to the public accountability of the Comrission and the consequent need to demonstrate its rational, professional, equalitarian nature, hence the adoption of the Weberian model. The second is the working model, made up of those elements within the agency that actually wield decision making power.

Organizational Structure of the Urban Renewal Bureaucracy

The organizational structure of the urban renewal bureaucracy is in itself relatively simple. It, like the action agency, adheres to a Weberian like public model while often working through a modification of that model in attaining its goals. The ideal, or public modei, may be defined as rigid, rational and formal organization with highly defined authority and communication channels, with the amount of power regulated by the position of the office within the hierarchy of the bureaucracy. Theoretically, each bureau has its defined furisdictional area arranged vertically in a Weberian styled ideal hierarchy. That is, each bureau has tts areas of responsibility, power, and control in relationship to the bureaucracy as a whole.

The controlling agency of this bureaucracy is the Department of Housing and Urban Deveiopment (HUD), which "governs" its subordinate bureaus through a system of rules, laws and regulations, and the allocation of federal funds. Thus, the administrators of HUD or bureau A, maintain their superior position as the head bureau with overriding 
authority over their suboxdinate buraaus. Though each of the subordinate bureaus is obligated to follow HUL's dictums, they in turn may require a subordirate bureau to follow rules andior regulations that they may design. The administrators of bureau $\mathrm{C}$, in other words, may be required to follow both $A^{\prime} s$ and $B^{\prime}$ 's regulations (with $A^{\prime}$ 's regulations having priority), create further regulations for 1.ts own jurisdictional area and add still more requirenents on to the action agency, bureau $D$, thus $D$ must follow the regulations of $A, B$, and $C$.

Though EUD malntalns several hundred action agencies, and several regional offices throughout the country, this study will focus on a model that is Indicative of the bureaucracy, but limited to one regional office and one action agency (see Figure VII).

This model, like the action agency's ideal model, is widely publicized and adhered to for most routine adminjstrative activities-for the same reason, public accountabjlity. HUD, and the entire urban renewal bureaucracy, including this model, is being continually examined, probed, investigated and monitored, by Congress, the mass media, interest and pressure groups, revolutionaries of all types, minority groups of every description, etc. A Weberian like model provides a structure for a maximization of accountability through rationalized administration, in that each bureau is responsible for its jurisdictional area with ultimate responsibility and authority at the top, the head bureau.

The Ideal model represents the organization of public record, like the action agency, the formal rules and regulations; the accounts of bureaucratic activities; the dispensing and withdrawing of funds from a program or project all follow this model. 


\section{FIGURE VII}

THE URBAN RENEWAL BUREAUCRACY: IDEAI MODEL

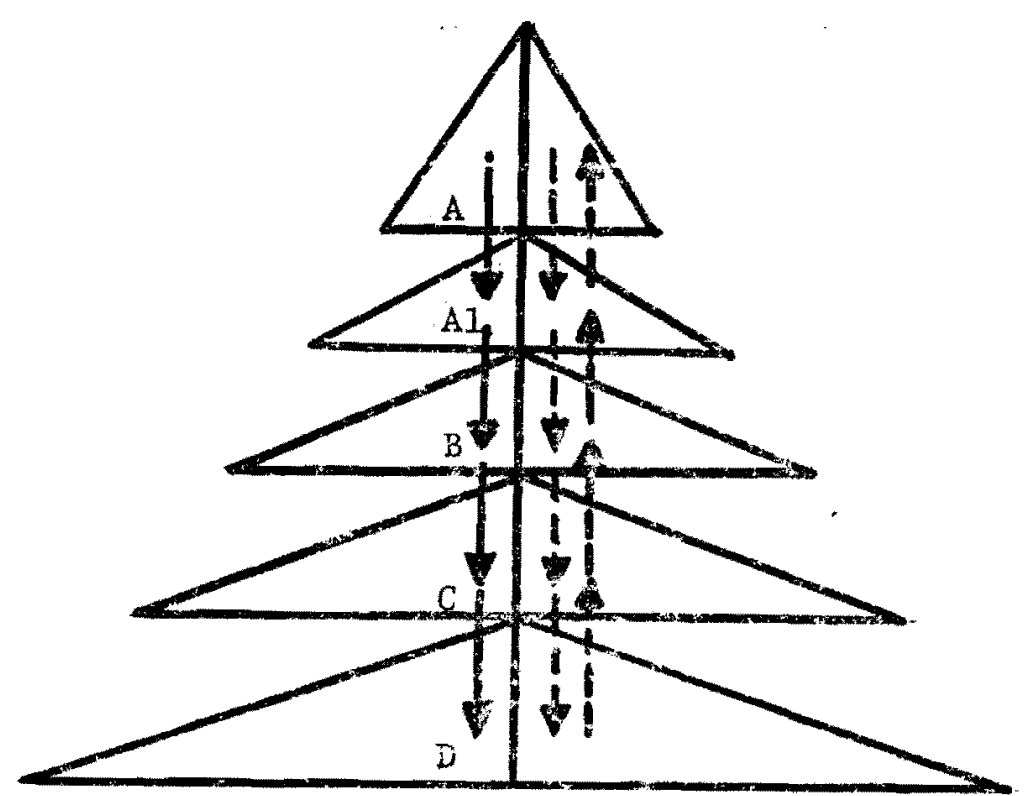

A. Department of Housing and Urban Development: Washington, D. C.

A1. Department of Housing and Urban Development: Regional Office, San Francisco, California.

B. City Council: McCannville.

c. Model Cities Citizen Planning Board: McCannville.

D. McCannville Developrent Commission. 
However weil designed, the ideal type bureaucracy often requires modification in light of: (1) fortuitous events; (2) rime limitations; (3) personnel weaknesses in critical positions within the bureaucracy; or (4) bureaucratic "reä-tape." As a result, the most common modifi-cation of the ideal bureaucracy is Iliustrated in Figure VIII.

The solid arrows represent lines of authority on a superordinate basis--while the broken arrows illustrate channels of communication. This figure demonstrates the rigidity of the ideal model, in that lines of authority and communication are arranged in terms of Weber's ideal model.

This model is most often used when there is a time limitation Involved that precludes the use of the j.deal model. An empirical example of the use of the working model involved the sudden availability of $\$ 100,000$ that needed to be dispensed to an action agency within (apparently) several hours. When the MDC was selected as a candidate for these funds, it was notified by telephone from the HUD offices in Washington, D. C., and given several hours to reply via the sane media. The working model of the action agency (see Figure V) responded by holdIng an immediate conference, and a decision was made to accept the $\$ 100,000$. The total time element suvolved from the initial receipt of the HUD notification of the funds, to acceptance, to HUD confirmation of the additional funds, was approximately two and cne half hours. The next day the staff of the MDC was verbally notified of the grant, but was warned that it was still a secret, and not yet ready for public consumption. In the meantime, as per HUD request, the MDC prepared a formal application for the additional $\$ 100,000$ to "supplement" the already 


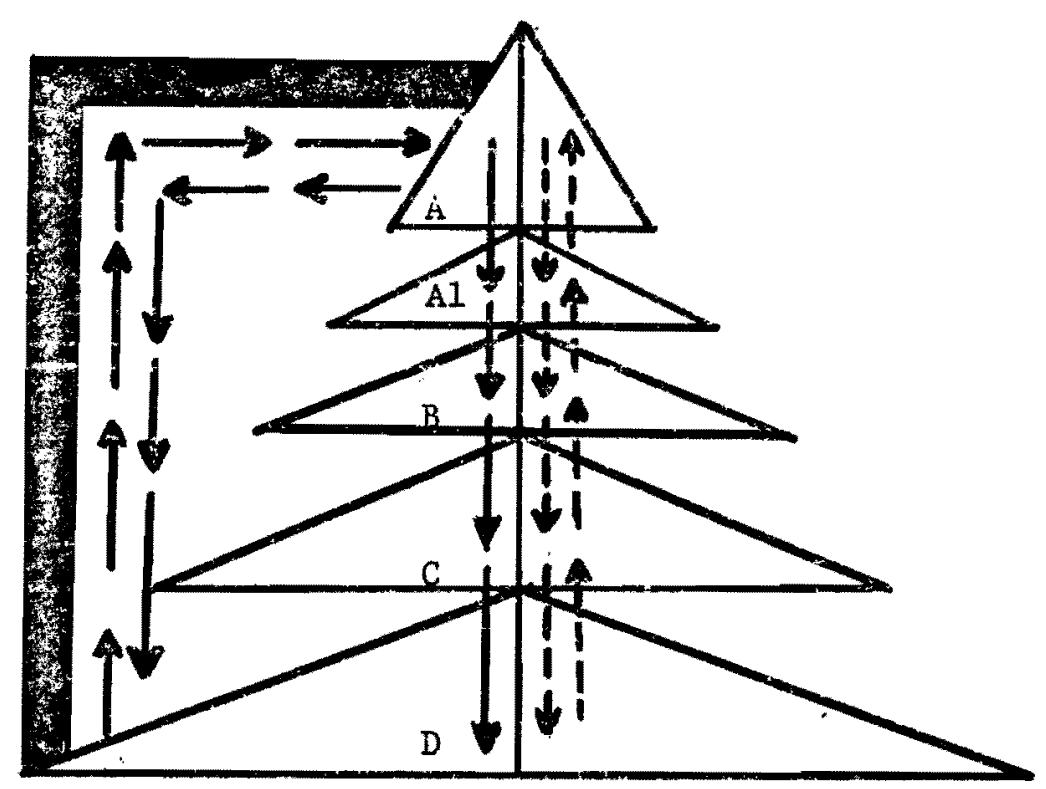

A. Department of Housing and Urban Development: Washington, D. C.

A1. Department of Housing and Urban Development: Regional Office, San Francisco, California.

B. City Council: McCannville

c. Model Cities Citizens Planning Board: MicCannville

D. McCannville Development Comission

This figure demonstrates a modification of the ideal public model. It is important to note that the modification is not an exclusive one, nor is it permanent, and that the public model is always in some form of operation. This particular modification illustrates HLD by-passing bureaus, $A I, B$ and $C$, dealing directly with the action agency, the McCannville Development Comisston. 
Efproved and funded Neighborhood Develoyment Program under the current administration of the XDC. This appilcation contained all the supporting data explaining the need for the additional. funds. Once the application was approved by bureaus $B$ and $C$, a senator from the state made a personal radio announcement of the additional $\$ 100,000$ granted to the McCannville Developwent Comission for urban renewal. No formal records were kept of the telephone conversations or agreements, caly fils copies of the formal application. This type of activity was not uncomon, and the results were fruitful in that: (1) the modification of the ideal model met the time requirement; (2) public accountability was met by filing a formal application through channels before it was publicly announced; and (3) a senator was able to make some "political hay" by announcing the "award" of the additional funds to the Neighborhood Development Program.

It is through the unrecorded modification of the ideal model that many critical decisions are made that affect the entire bureaucracy and urban renewal. However, it is normally the Ideal formal model that comes under the pubilic's scrutiny and comment.

The existence and the use of working models within the bureaucracy is a classic example of the differential enforcement of rules and regulations by the head bureau. Normative standards established by the administrators of HUD require that the designated channels of the ideal public model be used for reasons of public accountability, failure to comply with this standard without the explicit approval of HUD may mean actual loss of funds for existing or future programs. HUD, however retalns overriding authority of the sstablished bureaucratic mechanisms 
and may significantly compromise the ideal modei in the attainment of its goals. As demonstrated in the empirical example, HUD by-passed bureaus $A, B$, and $C$ and chose to deal directly with bureau $D$. Bureaus subordinate to HUJ likewise maintatn working models and use them in appropriate sttuations. The "appropriateness" of the use of the working model is largely determined by iud. The exlstence of the normatlve standards allows HUD to control its subordinate bureaus through the exercise of its sanctioning pover.

\section{Bureaucrats and Residents}

Maximization of citizen participation in the urban renewal process is a goal of the bureaucracy. It w11l be through the concept of citizen participation that the theoretical concepts of this paper will be further examined.

HUD has issued several directives pertaining to the role of citizens.' participation on the action agency level (HUD RHA 7100.1). The following are two abstracts taken from those directives.

Requirements for Citizen Involvement. A guiding principle of Departmental policy is to insure that citizens have the opportunity to participate in policies and programs which affect their welfare. Therefore, the workable program requires clear evidence that the commurity provides opportunities for citizens, including those who are poor and members of minority groups, to partictpate in a11 HUD assisted programs . . The community will also be expected to show what progress has been made during each certification period to achieve an adequate and effective degree of citizen involvement.

A more explicit statement appeared in a similar document of later publication (HUD RHA 7217.1):

It is HUD policy to assure that maximum opportunities are provided for citizen involvement in the planning, development and execution of progiams assisted by the Department. citizens should have clear and direct access to decisionmaking in all stages of the irban renewal process. 
These statements represent HUD's basic public position on citizen participation. When transwitted through the bureaucracy to the action agency. the policy becomes a requirement and a continual goal to be achleved over a period of time. HUD, however, leaves the cholce of mechanism for the exercise of citizen particlpation to the local community and the structure of the particular agency.

To the action agency, then, the requirement for citizen participation in tts programs becomes a part of its overall operation. in the case of the MDC, a separate staff section was designed to manage, report, organize and direct citizen participation as it related to Commission projects. During the perlod of this study, the citizen participation staff was the largest department in the agency with more than seventeen members.

HUD's requirement is relatively simple; citizens of the communities involved in HUD sponsored programs will participate in the planning, development and execution of those programs. The mechanism(s) through which this process occurs is largely left up to the action agency, but HUD requires that some sort of measurement of citizen participation be reported and that the process be continually expanding and tmproving. The coercive nature of this program is manifested through HUD's ability to deny or grant federal funds to action agencies. If the residents of a project area complain too bltterly about the action agency's tactics, programs and staffs involved in citlzen participation, the action agency is given opportunities to defend itself, but if the negative pressure on the part of the residents continues the agency stands a chance of not beling funded for that particular project the 
following year, or having the funds singly withlrawn. inat the HUD citizen participation policy has come to mean on the action agency level in essence is, citizens need to be "reutralized" through the participation process so that public dissention and opposition to urban renewal projects may be minimized. Aation agencies recelve no additional awards of funds for citizen participation, but stazd to lose greatly from citizen opposition, not only iocally through civic and court actions and an unpopular press, but way be denied funds for their projects from HUD. Denial of federal funds would mean all but closure to the MDC. Though HUD requires citizen participation, it has developed no monitoring system for $i . t$, and seems to have little Interest in it outside of a monthly numerical account of it, unless there are opposition and citizen complaints. HUD will tolerate distortion of this goal, until residents publicly demonstrate dissatisfaction; then it retains the right to sanction the action agency involved.

Citizen participation is not in itself a genuine process, but a constraining mechanism which this bureaucracy must contend with in achleving its goals.

The lesson for the community organization is plain: the function of citizen participation is to support, not to create. The function of the professional is to create (Kramer and Specht, 1969:57).

The MDC views citizen participation as still another obstacle in the process of urban renewal. It, at the same time, realizes the essence (as previously discussed) of the HUD requirement and submits monthly reports of citizens' participation in its various projects.

To the Commission, the idea of ordinary citizens actually taking part in complex planing, Wesign and execution of complex urban renewal 
profects seems much beyond the capabiliries of any citlzenry.

Such people are usually the objects of civic action; they are acted upon by others, but rarely do they themseives initlate action. As a result they often develop a keen sense of the difference between "we" and "they"--"they" being outside, city-wide civic and political forces which seek to police them, vote them, and redevelop them (Spiegel, 1968: 51).

Basically citizen participation for the "average" citizen in the project areas is beyond his means of experience in organized endeavors of this nature, and in excess of his time available for this kind of activity. ${ }^{1}$ It is a relatively easy process to obtain consent to renewal plans when people are thinking in terms of general goals and community-wide benefits, but it has proven mucis more difficult when the same people are shown the same set of facts in terms of personal threats and costs. As a consequence, through HUD sanction, the $M D C$, and most other action agencies, have chosen to work through neighborhood organizations representing the project areas involved. Thus, prograns and projects are sold to the residents on a broad good-for-the-conmonwealth basis.

Ideally, the concept of citizens' participation recognizes the vested interests and concerns of the residents involved in the projerts themselves, and as such, places some part of the power to shape or respond to such programs in their hands (Spiegel, 1968). Bur the ideal rarely becomes the real. The complexity of the factors involved in urban

1. Through the participant-observation experience, I learned that a majority of the population of the Hayes District shared little Interest in the concept of citizen participation, unless the fate of their own personal property was involved. 
planning require the combined skills of city planning specialists, engineers, architects, relocation staffs, finance experts, etc., but Congress, with the advent of the anti-poverty program, has required admin1strative agencies spending federal funds to maintain active programs of citizen participation. HUD has responded by developing a policy requiring citizen participation on the action agency level, but leaving the mechanism for it largely up to the action agency itself. The result has been the formal accounting of citizen participation through reports submitted to HUD on some type of regular basis, lisually monthly. In order to better facilftate the administrative mechanisms of HUD, the cltizen participation data (which is in reality largely subjective) is translated into numbers and given the required sinulacrum of objectivity.

The MDC has translated the citizer participation concept into terms of citizen neutralization as previously stated. Fublic, community confirmation and sanction of Commission urban renewal plans, is a useful inechanism in quelling the opposition of individual residents within the neighborhood and keeping publicity about its activities favorable.

The Role of the Community Association in Relation to Achieving Bureaucratic Goals

In an attempt to deal with the potentially unwieldily and chaotic process of citizen participation, IUD early in 1969 developed the concept of a Project Area Comrittee.

A Project Area Committee (PAC) made up of residents of a project area, shall be established for each urban renewal project in which residential . . activities are contemplated . . The (action agency) shall work closely with the PAC to assure that project residents paxticipate in the formulation and execution of plans for renewal of the area and improvement of the condition of its residents (HUD RHA 7217.5). 
In essence, this was a tremendous assist to the action agencles. It, for all practical purposes, meant the end of dealing with individual residents on matters of citizen participation, as they were now referred to their PAC. At this point the MDC was able to deal with one organization per project area, which greatly simplified its task. Regular meetings were established, chalrman and executive board members elected by local residents, and the Commission retained tight control.

The MDC organized the first PAC in McCannville and literally prepared the agendas for the meetings, typed the minutes, provided the meetIng places and served refreshments. The recoras of the PAC's meetings were (and still are) kept in the MDC files. Citizen participation in McCannulle was under the tight control of the MDC.

It did not take long, however, for at least some residents of the communities involved to sense that this process of participation was not 211 genuine, and low-keyed opposition began to be heard. At this point the citizen participation staff of the $\mathrm{MDC}$ realized that future PAC sanctions of MDC urban renewal programs might be jeopardized, and as a consequence two adjustments were made: (1) the manipulation of the appearance of power; and (2) the development of options to simulate choice.

First, the Comission realized that os long as the residents felt controlled by MDC, there would be reasonable grounds for opposition to its programs. As a result the Comission began to play oniy a minor role in public PAC meetings, answering an occasional technical question, serving refreshments, handing out agendas, and so on. Nothing really changed, only the manipulation of the appearance of power to the chairman of the PAC and their executive boards. Hence, the Comolssion 
monopolized on the fact that the source of power most easily manipulated 1s the sense of leadership in organized groups (Kramer and Specht, 1969:52). The chairman and his execurtve board would always meet with the Commission staff several days prior to the public general meeting. It is at these meetings that the Commission let its desires and needs be known. Opposition and problems are resolved at this level before the general nembership ever becomes involvea. In nearly all cases Involving the Hayes District Community Association the decisions are made to support the Commission program prior to the general membership meeting. It is at this level that whatever compromises are required are made, so that at regular public meetings of the Project Area Committee (PAC), the Commission is sure of support from the shatrman and the executive board.

Flgure IX represents a sequential list of meetings, their topics, and the ratio of MDC staff to HDCA members. It is important to note the attendance of MDC staff to $\mathrm{HDCA}$ meetings fluctuated with the nature and purpose of the meeting--the more critical the meeting in relation to MDC programming the more staff present.

A ratio of nearly one to one of staff to members, when a critical decision was to be made, leaves little doubt as to the nature of citizen participation in McCannville. The following quotation is not a universal truth, but it is indicative of the situation:

Sometimes when the community begjins to ask hard or embarrassing questions, professionals retire beneath a mantle of experience and qualifirations to demand that their judgments be accepted as revealed truth; administrators retreat behind a suoke screen of procedural objectives (Spiegel, 1968:67). 
FIGURE IX

HDCA MEETINGS - MAY 2, 1969 TO APRIL 20, 1969

\begin{tabular}{|c|c|c|}
\hline \multirow[t]{2}{*}{$5 / 2 / 69$} & $\begin{array}{l}\text { Type: } \\
\text { Purpose: }\end{array}$ & $\begin{array}{l}\text { Executive Board } \\
\text { MDC Introduces Nefghborhood Devel- } \\
\text { opment Program to Executive Board } \\
\text { (Nonpolicy Making) }\end{array}$ \\
\hline & Ratio: & 2 MDC Staff -10 Members $(1: 5)$ \\
\hline \multirow[t]{2}{*}{$11 / 16 / 69$} & $\begin{array}{l}\text { Type: } \\
\text { Purpose: }\end{array}$ & $\begin{array}{l}\text { General Membership } \\
\text { Election of Officers (Nonpolicy } \\
\text { Making) }\end{array}$ \\
\hline & Ratio: & 2 MDC Staff -27 Members $(1: 3.5)$ \\
\hline \multirow[t]{2}{*}{$11 / 19 / 69$} & $\begin{array}{l}\text { Type: } \\
\text { Purpose: }\end{array}$ & $\begin{array}{l}\text { General Membership } \\
\text { Introduction of Neighborhood Devel- } \\
\text { opment Program's Financial Aid } \\
\text { Program (Noncritical Policy Making) }\end{array}$ \\
\hline & Ratio: & 4 MDC Stafí - 20 Members $(1: 5)$ \\
\hline \multirow[t]{2}{*}{$12 / 9 / 69$} & $\begin{array}{l}\text { Type: } \\
\text { Purpose: }\end{array}$ & $\begin{array}{l}\text { Executive Board } \\
\text { Budget for Citizens' Participation } \\
\text { (Policy Making) }\end{array}$ \\
\hline & Ratio: & 3 MDC Staff - 10 Members $(1: 3.3)$ \\
\hline \multirow[t]{2}{*}{$1 / 7 / 70$} & $\begin{array}{l}\text { Type: } \\
\text { Purpose: }\end{array}$ & $\begin{array}{l}\text { Executlve Board } \\
\text { Acceptance of NDP Proposal (Critical } \\
\text { Pollcy Making) }\end{array}$ \\
\hline & Rat10: & 12 MDC Staff - 9 Members $(1: .75)$ \\
\hline \multirow[t]{2}{*}{$1 / 13 / 70$} & $\begin{array}{l}\text { Type: } \\
\text { Purpose: }\end{array}$ & $\begin{array}{l}\text { General Membership } \\
\text { Orientation to NDP by Staff (Policy } \\
\text { Making) }\end{array}$ \\
\hline & Rat1o: & 8 MDC Staff -20 Members $(1: 2.5)$ \\
\hline \multirow[t]{2}{*}{$1 / 27 / 70$} & $\begin{array}{l}\text { Type: } \\
\text { Purpose: }\end{array}$ & $\begin{array}{l}\text { Executive Board } \\
\text { NDP Proposal and Changes (Policy } \\
\text { Making) }\end{array}$ \\
\hline & Ratio: & 6 MDC Staff -13 Members $(1: 2.1)$ \\
\hline \multirow[t]{2}{*}{$2 / 10 / 70$} & $\begin{array}{l}\text { Type: } \\
\text { Purpose: }\end{array}$ & $\begin{array}{l}\text { General Membership } \\
\text { Financial Assistance Program under } \\
\text { NDP (Noncritica1) }\end{array}$ \\
\hline & Rat1o: & 9 MDC Staff -33 Members $(1: 3.7)$ \\
\hline
\end{tabular}


FIGURE IX continued . .

\begin{tabular}{|c|c|c|}
\hline $2 / 16 / 70$ & $\begin{array}{l}\text { Type: } \\
\text { Purpose: } \\
\text { Rat1o: }\end{array}$ & $\begin{array}{l}\text { Executive Board } \\
\text { Finai Approvel of Nop Proposal } \\
\text { (Critical Policy Making) } \\
6 \text { iidi Stafi - } 10 \text { Members }(1: 1.6)\end{array}$ \\
\hline $3 / 10 / 70$ & $\begin{array}{l}\text { Type: } \\
\text { Purpose: } \\
\text { Ratio: }\end{array}$ & $\begin{array}{l}\text { General Membership } \\
\text { Introduction of Park Site Concept } \\
\text { (Noncritica1) } \\
10 \mathrm{MDC} \text { Stafi }-24 \text { Members }(1: 2,4)\end{array}$ \\
\hline $3 / 31 / 70$ & $\begin{array}{l}\text { Type: } \\
\text { Purpose: } \\
\text { Ratio: }\end{array}$ & $\begin{array}{l}\text { Physical Pianning Committee } \\
\text { Park Site Location (Critical Policy } \\
\text { Making) } \\
7 \text { MDC Staff - } 5 \text { Members }(1: 1.4)\end{array}$ \\
\hline $4 / 5 / 70$ & $\begin{array}{l}\text { Type: } \\
\text { Purpose: } \\
\text { Ratio: }\end{array}$ & $\begin{array}{l}\text { Physical Planning Committee } \\
\text { Park Site Plan Approval (Critical } \\
\text { Policy) } \\
8 \text { MDC Staff - } 5 \text { Nembers }(1: .72)\end{array}$ \\
\hline $4 / 14 / 70$ & $\begin{array}{l}\text { Type: } \\
\text { Purpose: } \\
\text { Ratio: }\end{array}$ & $\begin{array}{l}\text { General Membership } \\
\text { Park Site Approval (Noncritjcal } \\
\text { Policy) } \\
9 \text { MDC Staff - } 102 \text { Members }(1: 12.7)\end{array}$ \\
\hline $4 / 20 / 70$ & $\begin{array}{l}\text { Type: } \\
\text { Purpose: } \\
\text { Ratio: }\end{array}$ & $\begin{array}{l}\text { General Membership } \\
\text { Park Site Approval (Noncritical Policy) } \\
9 \text { MDC Staff - } 115 \text { Members }(1: 12.4)\end{array}$ \\
\hline
\end{tabular}


The critical question seams to be whether or not the conditions necessary for successful citizen engagement in urban renewal are tolerable to the administrative, political and professional establishment in whose hands the Initiation of such activities lies. For citizen particlpation is a social invention developed outside of the urban renewal bureaucracy and merely aftxed to it. The concept of ordinary citizens taking part in improving the cowmunity is ccrtainly in keeping with the American jJeal of democracy. One finds 14ttle fault with the concept of citizen particlpation, but its practical application to urban renewal activities had ceriainly fallen short of any original expectations (in reality). Simply, federaliy sponsored urban renewal projects require dealing successfully with almost endless amounts of red tape. It has taken a long time for action agencies, model cities administrators and city governments to acquire the knowledge and experlence required for this. Any expectations that citizens of a given urban renewal project have the time, interest and skills required for meaningful participation falls in the realm of the ideal.

Although HUD requires citizens' participation on the part of its agencies it has also demanded, in the case of the MDC, that eighty percent (80\%) of the work be completed in the first year's proposal in the Neighborhood Development Program, or the second year's funds would not be allocated. The impact of this requirement was to almost totally nullify all but token citizen participation in the Hayes District, for it put the Commission on a rigid time schedule for the accomplishment of certain tasks.

Figure $X$ is a timetable established by the MDC for the addition of two lots to the park site in the Hayes Distrfct. 
FIGURE X

PROPOSED TIMFTABLE FOR PROCESSING THE HAYES DISTRICT URBAN RENEWAL PLAN SUPPLEMENT

Purpose of Supplement: Addition of two lots to Park at Corner of Claremont and Oneonta.

Date

July 21 Approval of Hayes District Community Association's Physical Environment Comm.ttee.

July 28 Approval of HDCA Executive Comnittee.

August $4 \quad$ Verbal contact, by telephone, with c1ty agencies asking approva1.

August 7-11 Draft supplement.

August 12 lail copies of urban renewal supplement to HUD, Modei Cities Citizen Planning Board, consultants and the president of the HDCA.

August $14 \quad$ Receive written agreements from city agencies.

August 17 MDC resolutions approving supplements.

August 19 Meeting of the HDCA general membership to approve addition to park.

August 21 Mail copies of supplement to Model Cities Special Projects Committee.

August 26 Approval of Special Projects Committee.

September 1 Receive HUD approval of supplement.

September 1 Approval of city council.

September 1 Approval of Model Cities Citizens Planning Board.

1. Taken from the actual Comission's timetable for the Hayes District. 
The HiJd requirewent for elghty percert (80\%) project completion of the first year's program or no funds for the second year is coercion. For the MDC, the Neighborhood Development Program pxovides approximately seventy-five percent (75\%) of its operating funds. Consequently, citizen participation becones citizen neutrallation so that the necessary work may be completed and the time schedule met. Seventeen full-time Commission staff are assigued to insure the success of this process. 
CHAPTER V

\section{CONCLUSTONS}

\section{What Has Been Discussed: A Brief Sumary}

A Weber like ideal type bureaucracy has become the public model fo: an urban renewal burcauczacy. The Weberian style model affords maximum public accountabilfty while maintaining a rational, logical structure of inter-bureau relationships. The publicly presented Image of the urban renewal bureaucracy is one of a smoothly and efficiently functioning organization based upon equalitarian principles. This image is so critical to the overall public perspective of the bureaucracy that the administration of it carefully records and documents the functioning of the Weberian model. What Weber intended to be an ideal type description of bureaucracy has manfested itself in the urban renewal bureaucracy as an ideology. For the Weberian 1ike Ideal type model has become the publicly presented image of the bureaucracy, and as such is related to the American political concept of a democratically run institution. The ideal model satisfies the political aspects of the federally run institution in relation to public accountability, whlie the working models tend to be actually responsible for carrying out the urban renewal processes. Because of the ideologic nature of the ideal model, records of its operation are carefully maintained in order to demonstrate the bureaucracy's commitment to it. No records tend to be kept of the activities of the working models because of the obvious contradictions to the ideal model; therefore, 
working wodels tend to be quasi-secret in nature. Thus, whatever Information is gained from or about the urban renewal bureaucracy is usually In keeping with the functloning of the Ideal mode1.

Citizen participation was affixed to the ideal model by the Congress of the United States. The concent of cltizen participation would logically seem to be an extention of the ideology attached to the ideal model. That is, an enlightened citizenry assisting a denocratically run bureaucracy was viewed by Congress as logical and destrable.

The bureaucracy responded by formally incorporating citizen participation into the functioning processes of 1 ts ideal model. How the Ideal and working models of an action agency dealt with citizen participation was the essence of this thesis.

During a nine month particlpant-observation study of an action agency, the "MDC," the author became aware of the models operating withIn the Ideal public model. These "other" models were designated real or working models, and it was noted that they tended to exist on both interbureau and bureau levels. These working models seemed to have more power in the actual administration of urban renewal activities than the Ideal model. Working models co-exist with the Ideal type, but because of their contradictory nature in relation to the ideal model, their activities tend to be unrecorded.

Whereas, the operation of the ldeal type model is theoretically based upon concepts like cooperation, equalitarlan principles, and adherence to an established hierarchy of authority, the working model seems to function on concepts like coercion, differentlal enforcement of rules and regulations, and the distortion of goals. It is important to note that the function of both real and Ideal models is to achieve 
the formal goals $c^{f}$ the burecucracy.

Chapters three and four illustrate the concepts of real and ideal models on inter-bureau and bureau levels respectively. The concept of citizen participation as a requirement in the urban renewal process on both levels provided a focus for the demonstration of both real and ideal models.

\section{Some Lessons Learned}

What essentially happens in the urban renewal bureaucracy is that the administration views its goals in terms of the overall society; consequently the importance of the "end resuits" seems to have precedence over how they are accomplished; 1.e. if the pervasive society is supportive of the ideal model and its goals, the urban renewal bureaucracy reports its activities in those teras--regardless if it functions in those terms or not.

The result of these phenomena, in terms of the effect on those Individuals subject to the urban renewal process, are considerably consequential in that they are further removed from realizing any "volce" in the urban renewal process in their neighborhood. The resident is nearly totally "neutralized" by the concept of citizens' participation itself. He is officially required to use the mechanism of the Project Area Commttee, i.e. the HDCA, to voice his opinion on policy and decision making. The existence of $\mathrm{MDC}$ established cltizen participation mechanisms tend also to mean MDC control over its activities; the resident then, is forced to deal with an exclusive mechanism for the exercise of his "right" to participate in the urban renewal process. The residents tend to be "co-opted" by an organization that was forrally 
established to insure their active participation in the urban renewal process. Thus, if a resident vants to oppose an MDC plan or program he must do so through the Project Area Committee, which, as has been illustrated, is largely controlled by the IDC. If the resident wishes to carry on his oppositicn, it will be in terms of opfosing his neighbors' approved programs and plans, for the $\mathrm{MDC}$ ises the project area comittees to gain public neighborhood consent and approval for its programs. Thus, the resident is faced with opposing his intends and neighbors instead of the Commission.

Although the study of real and ideal bureaucratic models is not new to sociology, the study of them in relation to particular bureaucracies can make additions to the understanding of them. The complexity of our society may be mirrored in the ccmplexity of our bureaurcracies, and efforts to further the understanding will hopefully be beneficial to the society.

In addition to gaining general understandings of the functioning of a bureaucracy and how that functioning affects those parts of society that it comes in contact with, specific knowledge of working and ideal models may advance the ability of individuals who must deal with bureaucracies on the level discussed in this thesis to cope with them. With an understanding of the existence of working and ideal models, citizen groups, such as the HDCA, might be made sophisticated, more knowledgeable, and perhaps even more powerful in taking part in the actual urban renewal process. If these thoughts seem a bit idealistlc, the author pleads guilty. 
Thoughts for Future Study

This thesis illuminates the need for future study fn the operation of working and ideal models in complex organizations. The fmplications of their existence and operation in the urban renewal bureaucracy raises the question of the extent of their universality in other complex organizations, and of the extent that the organization's "client" may or may not be subject to the operation of both working and real models. With the advent of state revenue sharing, the speculation that citizen participation would be even further diluted, is not an unreasonable forecast. For whatever cursory control that the administrators of HUD maintained over the action agency in the realm of citizen participation would be given up to individual states, and consequently to the cities carrying out urban renewal projects within the state, a probable result being the concept of city-ride citizen participation, regulated by the action agency rather than citizen participation in each project area. Consequently, in the city-wide race and competition for avallable funds, the best organized, influential, powerful, and polftically adept groups would undoubtedly receive preferential treatment, leaving those groups with little organization and resources with ifttle hope of assistance. 


\section{REFERENCES}

Altshuler, Alan A., (1968), The Politics of the Federal Bureaucracy. New York: Dodd, Mead and Company.

Andrews, Rlchard B., (1962), Urban Growth and Development. New York: Simmons-Boardman Publishing Corporation.

Becker, Howard S., (1970), Sociological Work. Chicago: Aldine Pub11shing Company.

Bergel, Egon E., (1955), Urban Society. New York: McGraw-Hill Book Company, Inc.

Beshers, James M., (1962), Urban Social Structure. New York: The Free Press of Glencoe, Inc.

Blau, Peter M., (1955), The Dynamic of Bureaucracy. Chicago: The University of Chicago Press.

Blau, Peter M., and Scott, W. Richard, (1952), Formal Organizacions. San Francisco: Chandlex Publisining Cowpany.

Bloomberg, Warner Jr., (1968), Power, Poverty and Urban Policy. Beverly Hills: Sage Publicaticns, Inc.

Burgess, Ernest W. and Bogue, Donald J., ed., (1964), Urban Sociologx. Chicago: The University of Chicago Press.

Dahl, Robert A., (1961), Who Governs? New Haven: Yale University Press.

Dahl, Robert A., and Lindblom, Charles E., (1953), Politics Economics and Welfare. New York: Harper and Row Publishers.

Dahrendorf, Ralf, (1959), Class and Class Conf1ict in Industrlal Society. Stanford: Stanford University Press.

Doby, John T., (1954), An Introduction to Social Research. Harrisburg: The Stackpole Company.

Downs, Anthony, (1966), Inside Bureaucracy. Boston: Little, Brown and Company Limited.

Duhl, Leonard J., (1963), The Urban Condition. New York: Basic Books, Inc.

Etzioni, Amitai, (a), (1951), A Sociological Reader On Complex Organizations. New York: Holt, Rinehart, and Winston, Inc. 
Etzioni, Auitai, (b), (1961), A Comparative Analysis of Compiex Organizations. New York: The Free Press.

Faris, R. E. L., (1966), Handbook of Modern Sociology. Chicago: Rand McNally and Company.

Frieden, Bernard J., (1968), Urban Planning and Social Yolicy. New York: Basic Books, Inc.

Gerth, H. H., and Mills, C. Wright, (1958), Erom Max Weber: Essays in Sociology. New York: Oxford Untversity Press.

Gouldner, Alvin W., (1954), Datterns of Industrial Bureaucracy. New York: The Free Press of Glencoe.

Gross, Bertram M., (1964), Organizations and Their Managing. New York: The Pree Press.

Hawley, Willis D., and Wirt, Frederick M., ed., (1968), The Search for Comnunity Power. New Jersey: Prentice-Hall, Inc.

Hunter, Floyd, (1953), Community Power Structure. Chapel Hill: University of North Carolina Press.

Kramer, Ralph M., and Specht, Harry, (1969), Readings in Community Organization Practice. New Jersey: Prentice-Hall, Inc.

La Palombara, Joseph, (1963), Bureaucracy and Polftica1 Development. New Jersey: Princeton University Press.

Lindblom, Charles E., (1968), The Policy-Making Process. New Jersey: Prentice-Ha.l, Inc.

Mailick, Sidney, (1962), Concepts and Issues in Administrative Behavior. New Jersey: Prentice-Hali, Inc.

Nisbet, Robert A., (1970), The Social Bond. New York: Alfred A. Knopf.

Peabody, Robert L., (1964), Organizational Authority. New Yorl: Atherton Press.

Spiege1, Hans B. C., (1968), Citizen Participation in Urban Renewal. Washington: NTL Institute for Applied Behavioral Science.

Thompson, Victor A., (1961), Modern Organizations. New York: Alfred A. Knopf.

Tullock, Gordon, (1965), The Politics of Bureaucracy. Washington, D. C.: Public Affairs Press.

Webb, Eugene J., Campbe11, Donald I., Schwartz, Richard D., Sechrest, Lee, (1966), Unobtrusive Measures. Chicago: Rand McNally and Company. 
Weber, Max, (1968), Economy. and Society, Guenther Roth and Claus Wittich, ed., New York: Bedminister Press.

Weber, Max, (1947), The Theory of Social and Econouic Organization. Trans. A. M. Henderson and T. Parsons, New York: Oxford University Prass.

Whyte, William H., Jr., (1956), The Organization Man. New York: Doubleday and Company.

Perlodicals:

Bendix, Reinhard, "Bureaucracy: The Problem and Its Setting," American Sociological Peviev, Vol, 12, No. 5, October 1947, 493-507.

Bierstedt, Robert, "Analysis of Social Power," American Sociological Review, Vo1. 15, No. 6, December 1950, 730-738.

Blau, Peter M., "The Hierarchy in Organization," Anerican Journal of Socjology, Vol. 73, No. 4, January 1968, 455-466.

Etzioni, Anitai, "Authority Structure and Organizational Effectiveness," American Sociological Quarterly, Vol. 4, 1959, 43-67.

Goidberg, Aithur, "Communication in Large Organizations," 1970 Public Welfare Directory. Chicago: American Public Welfare Association, 1970.

Hal1, Richard H., "Intraorganizational structural Variation: Application of the Bureaucratic Model," American Sociological Quarterly, Vol. 7, No. 3, December 1962, 295-308.

Janowitz, Morris, "Changing Patterns of. Organizational Authority," American Sociological Quarterly, Voi. 3, 1959, 473-493.

Litwak, Eugene, "Models of Bureaucracy Which Permit Conflict," American Journal of Sociology, Vo1. 1\%, Nc. 2, September 1961, 177-1.84.

LPA Admintstration. Fashington: HUD Publication RHA 727..1, February, 1963.

Reich, Charles A., "The Greening of Anerica," The New Yorker. Sepienber $26,1970,40-55$.

Simpson, Richard L., "Vertical and Horizontal Commuication in Formal Organizations," American Sociologicai Quar:eriy: Vol. 4, 1959, $188-196$.

Udy, Stanley H., "Bureaucracy and Rationality in Weber's Organizational Theory: An Fupirical Study," American Sociological Review, Vo1. 24, No. 5, December i959, 791-795. 
Heiss, R. S., and Jacobdon, Eugeno, "A Method for the Analysis of tinc Structure of Complex Organizations," Anerican Sociological Review, Vol. 20, 20. 6, Decernber 195 $\overline{5,661-668 .}$

Workable Program for Community Improvement. Washington: HuD Publication RriA 7100.1, November 1963. 